
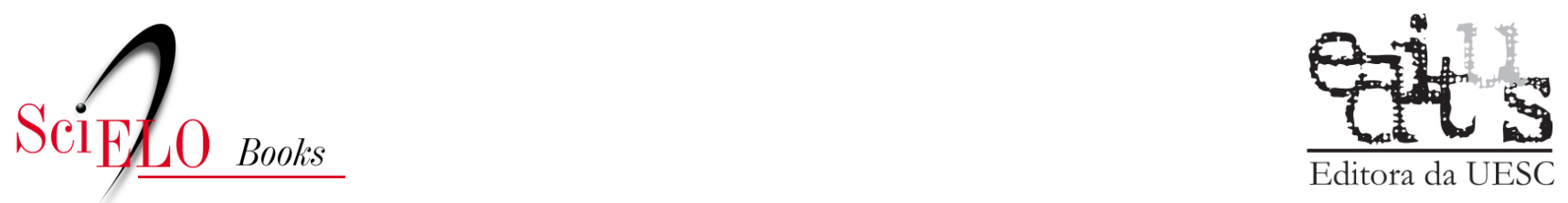

$\overline{\text { Editora da UESC }}$

\title{
Capítulo II - O aldeamento de ferradas e a ocupação territorial de Cachoeira de Itabuna
}

\author{
Ayalla Oliveira Silva
}

SILVA, A.O. O aldeamento de ferradas e a ocupação territorial de Cachoeira de Itabuna. In: Ordem imperial e aldeamento indígena: Camacãns, Gueréns e Pataxós do Sul da Bahia [online]. Ilhéus:

Editus, 2018, pp. 86-145. ISBN: 978-85-7455-528-7. https://doi.org/10.7476/9788574555287.0003.

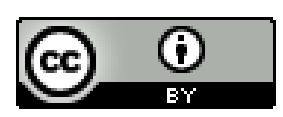

All the contents of this work, except where otherwise noted, is licensed under a Creative Commons Attribution $\underline{4.0 \text { International license. }}$

Todo o conteúdo deste trabalho, exceto quando houver ressalva, é publicado sob a licença Creative Commons Atribição 4.0. 
CAPÍTULO II 


\section{O ALDEAMENTO DE FERRADAS E A OCUPAÇÁO TERRITORIAL DE CACHOEIRA DE ITABUNA}

O aldeamento São Pedro de Alcântara, instalado na região sul da Bahia, em início do século XIX, também denominado, na documentação, como aldeamento de Ferradas, aparece descrito ora como freguesia, ora como vila e ora como aldeia por todo o tempo de vigência. Esse modo confuso de definir a categoria administrativa do estabelecimento se vincula ao próprio contexto de sua fundação e permanência. A fundação do aldeamento São Pedro de Alcântara compreende o final do período colonial, no qual se criam as vilas ${ }^{1}$ e freguesias ${ }^{2}$ nos antigos aldeamentos da capitania e posterior comarca de Ilhéus, e se estende à administração política imperial.

Contudo, a documentação analisada não fornece indícios para caracterizarmos aquele estabelecimento como vila, pois, segundo Marcis, a instituição de vilas "exigia o

1 Ver MARCIS, Teresinha. A integração dos índios como súditos do rei de Portugal: uma análise do projeto, dos autores e da implantação na Capitania de Ilhéus, 1758-1822. Tese de doutorado. Universidade Federal da Bahia. Salvador, 2013, p. 196: Segundo a autora, em 1759, o ouvidor Freire de Veras seguiu para a Capitania de Ilhéus a fim de realizar trabalhos de reformas nos aldeamentos, que compreendiam a instalação das vilas.

2 Cf. MARCIS, Teresinha. Idem, p. 218: O mesmo ouvidor Freire Luís de Veras havia sido responsável por redefinir as freguesias de Ilhéus nos moldes do arcebispado baiano, após a expulsão dos jesuítas. 
cumprimento de um ritual de demonstração da presença real, um aparato da administração da justiça e princípios que formalizavam os laços de fidelidade com o monarca" ${ }^{\prime 3}$. Também não existem indícios de que fosse efetivamente uma freguesia, "menor jurisdição eclesiástica, geralmente equivalente à civil da povoação ou vila" ${ }^{4}$. Neste trabalho, analisaremos o estabelecimento de Ferradas na sua dimensão de aldeia ou aldeamento, categoria administrativa da política indigenista colonial e imperial.

$\mathrm{Na}$ carta enviada pelo desembargador e ouvidor da comarca de Ilhéus ao Secretário de Estado da Marinha e Ultramar, Antônio de Araújo Azevedo, de 24 de maio de 1814, Balthazar da Silva Lisboa relatava a transferência dos índios do Almada para a região do rio Cachoeira ${ }^{5}$, onde funcionaria, a partir de então, o aldeamento São Pedro de Alcântara ou aldeamento de Ferradas.

Na correspondência, o ouvidor notificou o feito como se fosse uma vitória da civilização representada pela Coroa. Em homenagem ao príncipe regente, deu à nova povoação o nome de São Pedro de Alcântara, marcando a sua fundação para agosto, mês do aniversário do homenageado ${ }^{6}$.

Antônio Guerreiro de Freitas e Maria Hilda Baqueiro Paraíso, sob a ótica dos acontecimentos coloniais no Brasil em início do século XIX - transferência da família real para a colônia e crise de abastecimento agrícola para o mercado interno -, observam que 1808 se configuraria como marco

3 MARCIS, Teresinha. Op., cit., p. 205.

4 Idem, p. 218.

5 Idem, ibidem

6 Idem, ibidem. 
para a solidificação da produção de abastecimento interno, tendo o Rio de Janeiro como polo consumidor. Nessa direção, o deslocamento de mão de obra das zonas econômicas em crise, como a da mineração, para áreas de expansão agrícola colocaria em evidência a política de expansão territorial com base na apropriação de terras não colonizadas e utilizáveis.

Na região sul da Bahia, os deslocamentos econômicos para as novas áreas de interesse de expansão territorial, bem como abertura de estradas incidiram em maiores conflitos com as populações indígenas, habitantes daqueles territórios que, historicamente, resistiam ao processo colonizador, sobretudo os genericamente denominados botocudos. Esse termo traz em si o sentido pejorativo, que traduz a visão de animalidade e ferocidade que os colonizadores estabeleceram para tratar as populações resistentes ao processo da expansão territorial, durante o século XIX. Como observa Izabel Missagia de Mattos, o nome genérico, contudo, "abriga diversos subgrupos inter-relacionáveis"7. Apesar disso, a documentação produzida durante o século XIX poucas vezes nos permite enxergar os distintos grupos étnicos, pois a ideia era mesmo a de torná-los uma única massa, a dos "selvagens botocudos".

Nesse contexto, nas falas das autoridades provinciais e religiosas, os botocudos, habitantes das áreas ainda não ocupadas pelo Império, e resistentes ao processo de expansão territorial e construção de estradas, eram forjados como exemplo do malogro do projeto de ocupação e colonização e tidos como o maior obstáculo para o projeto econômico da família de Gonçalves da Costa, situação descrita por Paraíso como estopim para deflagração da Guerra Justa na região.

7 MATTOS, Izabel Missagia de. Civilização e revolta: os Botocudos e a catequese na Província de Minas. Bauru, SP: EDUSC, 2004, p. 30. 
A família Gonçalves da Costa foi beneficiada por concessão de sesmaria na região da Vila Imperial da Vitória (Vitória da Conquista), e levava à frente, naquela localidade, o projeto de implantação da pecuária. O desenvolvimento da pecuária e a formação de corredores de comércio com a abertura de estradas, a exemplo da estrada Ilhéus-Conquista, se configuraram nos principais motivos dos conflitos com os índios, segundo Paraíso ${ }^{8}$.

Portanto, em 1808 são decretadas, pelo Príncipe Regente, Cartas Régias declarando Guerra Justa aos “botocudos", visando "desinfetar os sertões" isso significava, nas palavras de Freitas e Paraíso, "garantir a mão de obra escrava aos novos conquistadores, abrir novas estradas e viabilizar a colonização de novos espaços"..$^{10}$

Com relação à Capitania de Ilhéus, segundo Freitas e Paraíso, o governo delegou aos capitães-mores da região a aplicabilidade das medidas determinadas pela Carta Régia de 1808, que declarava Guerra Justa aos "botocudos". Nesse contexto, a figura de Gonçalves da Costa seria fundamental, tendo em vista que o Capitão-mor teria prestado "relevantes serviços (...) na Conquista da Ressaca, onde organizara entradas nos vastos sertões de Gavião, Tamboril, Sucessos e rio de Contas. Segundo o Conde de Linhares, o seu trabalho se constituíra em liberar esses terrenos das incursões dos Botocudos e Pataxós

8 PARAÍSO, Maria Hilda Baqueiro. “Os Botocudos e sua trajetória histórica". In: CUNHA, Manuela Carneiro da (Org.). História dos índios no Brasil. São Paulo: FAPESP, Companhia das Letras, 1992, pp.416-417.

9 FREITAS, Antônio Guerreiro de; PARAÍSO, Maria Hilda Baqueiro. Caminhos ao encontro do mundo: a capitania, os frutos de ouro e a princesa do sul- Ilhéus, 1534-1940. Ilhéus: Editus, 2001, p. 51.

10 Idem, Ibidem. 
e aldear outras tribos mansas"11. De acordo com Paraíso ${ }^{12}$, era premente o interesse de Gonçalves da Costa e sua família em colonizar a região e facilitar o acesso e o escoamento de seus produtos e tropas para outras regiões.

Um dos focos principais para garantir o sucesso do projeto de colonização da região da Capitania de Ilhéus era a estrada que acompanhava o curso do Rio Pardo, e que ligaria Ilhéus, Conquista e Minas Gerais. "Em 1810", escrevem Freitas e Paraíso, "o engenheiro Felisberto Caldeira Brant foi nomeado para realizar estudos acerca da viabilidade do projeto"13; e optou por começar a abertura da estrada pelo curso dos rios Salgado e Cachoeira. No entanto, o projeto de abertura da estrada esbarrou nas dificuldades impostas pela presença massiva de indígenas não aldeados e resistentes ao projeto colonizador.

Em início do século XIX, por designação governamental, o ouvidor Balthazar da Silva Lisboa avaliaria as dificuldades relacionadas à construção da estrada entre Ilhéus e Minas, e concluiu que os grande problemas eram a ausência de colonos na região e a grande quantidade de índios não aldeados, que dificultavam o trânsito de viajantes e inviabilizavam o uso da estrada ${ }^{14}$. Havia crescente interesse governamental pelas terras ainda não colonizadas e cultivadas, pela construção da estrada como empreendimento que viabilizasse o trânsito de pessoas e mercadorias, bem como pela entrada de

11 Ofício enviado ao Conde da Ponte, Governador da Capitania da Bahia, Rio de Janeiro; 19/8/ 1809, Seção Decretos e Cartas Régias, Maço 1809, apud, FREITAS, Antônio Guerreiro de; PARAÍSO, Maria Hilda Baqueiro. Op., cit., 51-52.

12 PARAÍSO, Maria Hilda Baqueiro. Op., cit., 1992, p. 413-430.

13 FREITAS, Antônio guerreiro de; PARAÍSO, Maria Hilda Baqueiro. Op. cit., p. 52.

14 Idem, p. 53. 
colonos na região, que intensifica no sul da Bahia, no início do século XIX, a política de implantação de aldeamentos de catequese dos indígenas.

Conforme os quadros das aldeias da Província da Bahia do século XIX (Anexos 1 e 2), a política de aldeamentos de catequese seguiu na pauta governativa da Província da Bahia de forma crescente até a segunda metade daquele século, com foco nas questões sobre a colonização das terras e o aproveitamento do trabalho dos índios. Para a bibliografia especializada, a exemplo de Manuela Carneiro da Cunha, os interesses em torno da legislação indigenista e a problemática territorial sofreram mudanças ao longo do século XIX.

Note-se, contudo, que a política imperial valorizava o trabalho e a mão de obra indígena no processo da colonização, embora a apropriação territorial e a segurança dos colonos despertassem maior interesse e atenção da política indigenista daquele momento. Nas correspondências oficiais do período, trocadas entre autoridades locais e provinciais, o assunto trabalho indígena é uma preocupação constante e testemunha a continuidade efetiva da prática de uso intensivo desta mão de obra nas áreas de atuação dos aldeamentos. A exemplo de São Pedro de Alcântara (ver Anexo 3, Tabela 5), persiste, na segunda metade do século XIX, um evidente interesse pela mão de obra indígena, que recaía no cultivo da ascendente lavoura do cacau, principalmente.

As questões trabalho e apropriação territorial serão mais bem analisadas no terceiro capítulo. Por enquanto, podemos observar, nos quadros apresentados, o movimento de instalação de aldeamentos de catequese ao longo do século XIX. Observe que o total de aldeamentos existentes na Província da Bahia é apontado de forma imprecisa nos quadros dos Anexos (1 e 2). O Quadro de 1855 traz o 
total de 31 aldeamentos, e o de 1861, 36 aldeamentos. No entanto, é sabido que existiam outros estabelecimentos de índios aldeados naquele período, cujos nomes não constam nos mapas, à exemplo do de Verrugas ${ }^{15}$, localizado próximo a Conquista.

Outro ponto a ser frisado nessa etapa do texto é acerca das informações trazidas nos quadros sobre a situação jurídica das terras de cada aldeamento, condição apresentada de forma obscura porque não demonstra a situação territorial para todos os aldeamentos, e as que são citadas, o são de forma incompleta. As informações não nos permitem identificar minimamente se as terras de todos eles eram demarcadas, sua extensão ou a que administração estavam submetidas (se às Câmaras ou particulares, por exemplo). Sobre os aldeamentos de Ilhéus, por exemplo, o Quadro 1 (Anexo 1) não traz informação sobre a extensão territorial de nenhum deles; apenas acerca de dois deles existe a informação da demarcação ou não demarcação de suas terras. Nessa etapa, além do aspecto jurídico, atentaremos para a questão do cultivo das terras dos aldeamentos. A meta agora é a de explicitar, conforme as fontes permitam, como se dava o movimento de territorialização das populações indígenas na Bahia oitocentista, um dos nossos objetivos.

João Pacheco de Oliveira utiliza a noção de território para pensar sociedades cuja formação tem o território como o fator que regula as suas ações. Ele sugere que a incorporação de uma sociedade à situação colonial é um dos elementos mais significativos de sua transformação

15 CAMPOS, João da Silva. Crônicas da Capitania de São Jorge dos Ilhéus. Rio de Janeiro: MEC-CFC, 2006, p. 369. 
de sociedade segmentar em sociedade centralizada. ${ }^{16}$ Nesse sentido, a presença colonial "instaura uma nova relação da sociedade com o território, deflagrando transformações em múltiplos níveis de sua existência sociocultural". ${ }^{17}$ Oliveira propõe a noção de territorialização enquanto um ato político, no qual o conjunto de indivíduos ou grupos é enquadrado em determinado espaço geográfico. Esse ato político constitui objetos étnicos através dos mecanismos políticos arbitrários e exteriores ao grupo e às relações estabelecidas "entre os diferentes grupos que integram o Estado".$^{18} \mathrm{Na}$ perspectiva de Pacheco de Oliveira, a noção de territorialização deve ser tratada como um processo de via dupla, no qual os índios se apropriam do território delimitado pela agência colonial e participam diretamente de sua construção a partir das suas próprias motivações e interesses. $\mathrm{O}$ conceito de territorialização norteia nosso estudo no sentido de permitir pensar a instauração do aldeamento de Ferradas em dois níveis de análise: como mecanismo de intervenção dos governos colonial e imperial sobre os Camacãs, Pataxós e Gueréns daquela parte do sul da Bahia e, pensar como os aldeados, nas relações estabelecidas com os diversos agentes da colonização, no processo de territorialização, foram capazes de reconfigurar suas vidas na realidade colonial.

$\mathrm{Na}$ província da Bahia registrou-se no quadro de 1855, a atuação de 31 aldeamentos de catequese e no Quadro de 1861, um total de 36 aldeamentos, como já mencionado anteriormente. Não se trata de números exatos, pois

16 OLIVEIRA, João Pacheco de. "Uma etnologia dos índios misturados?" Situação colonial, territorialização e fluxos culturais. Mana. Rio de Janeiro: PPGAS Museu Nacional UFRJ, vol. 4, n. 1, 1998, p. 54.

17 Idem, Ibidem.

18 Idem, p. 56. 
os próprios registros existentes na documentação do período discorrem sobre as dificuldades de acesso a tais informações. No entanto, os quadros (ver anexos 1 e 2) nos permitem perceber, dentre outras questões importantes, onde estavam localizados os aldeamentos nas comarcas e nos municípios, bem como os fluxos das pessoas aldeadas.

Da mesma forma, ainda que não disponhamos de outros quadros demonstrativos referentes às décadas anteriores, podemos inferir que as informações disponíveis sobre a década de 1850 e início da década de 1860 delineiam um processo de continuidade da política de aldeamento e colonização regional iniciada antes, a exemplo dos aldeamentos coloniais de Abrantes, Santarém, Barcellos e São Fidelis. Ao longo do século XIX foram instituídos outros, a exemplo do objeto de estudo em questão, o aldeamento São Pedro de Alcântara. O estudo de Marcis traz as informações que nos permitem perceber a atuação inicial da política indigenista colonial na região.

$\mathrm{Na}$ Bahia, os aldeamentos jesuíticos passaram a atuar a partir de 1558 . Os primeiros aldeamentos foram estabelecidos em Salvador e no Recôncavo. Os aldeamentos de catequese só começaram a acontecer na Capitania de Ilhéus "após a guerra empreendida contra os tupiniquins, ordenada e conduzida pessoalmente por Men de Sá"19, em 1559. A partir de então, outros tupiniquins formaram aldeamentos como os de São Miguel, em 1561, e os de Nossa Senhora de Assunção, ambos em Camamu. Teresinha Marcis salienta que as populações aldeadas eram constantemente acometidas por epidemias, que tinham como principal motivo o modelo de aldeia adotado pela companhia jesuítica, de aglomerar uma vasta quantidade

19 MARCIS, Teresinha. Op., cit., p. 189. 
de índios num mesmo aldeamento. Salienta, ainda, que os aldeamentos jesuíticos foram constantemente reconstruídos e remanejados ${ }^{20}$.

Sobre outros aldeamentos coloniais, Marcis observa que, na ocasião da vinda do ouvidor Freire de Veras para a Capitania de Ilhéus, em 1759, a fim de realizar trabalhos de reforma nos aldeamentos, que compreendiam a instalação das vilas ${ }^{21}$, constatou não se ter uma definição clara para a data de criação do aldeamento de Nossa Senhora da Escada dos Ilhéus, vila de Olivença. No entanto, o primeiro registro de batismo data de $1682^{22}$. Já o aldeamento de Nossa Senhora das Candeias de Maraú, vila nova de Barcelos, tinha sua fundação correspondente a 1690, visto que seu primeiro registro de batismo data desse período, aproximadamente. Segundo Marcis, os indígenas de ambos os aldeamentos eram tupis, como descrevia o ouvidor Freire de Veras; outro aldeamento visitado pelo ouvidor foi o de Santo André e São Miguel do Serinhém, Vila Nova de Santarém. Embora o primeiro sacramento registrado tenha ocorrido em 1672, existe a possibilidade de sua existência inicial ter ocorrido em décadas anteriores ${ }^{23}$.

Teresinha Marcis observa, em seu estudo, que os aldeamentos instalados pelos padres jesuítas na Capitania de Ilhéus tiveram um tempo longo de atuação, porque mantinham a característica de agregar novos aldeados permanentemente, o que lhes garantia manter a estabilidade dos aldeamentos ${ }^{24}$. Dessa forma, em meados do século XIX coexistiam antigos aldeamentos coloniais

20 MARCIS, Teresinha. Op., cit., p. 191

21 Idem, p. 196.

22 Idem, p. 197.

23 Idem, p. 199.

24 MARCIS, Teresinha. Op., cit., p. 215. 
juntamente com aqueles instalados no período imperial, conforme demonstra o quadro dos aldeamentos da província da Bahia, de 1861.

Embora haja obscuridades nos quadros demonstrativos dos aldeamentos da Província da Bahia, nos quais muitas informações são omitidas, e em outros aldeamentos quase nenhuma informação se obtenha, cruzando os dois quadros podem ser percebidos aspectos importantes sobre a dinâmica da colonização e do trabalho indígena na Bahia oitocentista. A obscuridade do documento diz respeito, sobretudo, à situação das terras dos aldeamentos. O quadro 2 (anexo 2), por exemplo, cita que haviam terras cultivadas com vários gêneros e que haviam terras não cultivadas por índios. No entanto, omite a situação de cultivo das terras de diversos aldeamentos, e com referência aos de Ilhéus, não dispõe de dados sobre nenhum deles. Além disso, no quesito ocupação dos índios, nada consta a respeito. No quadro 1 (anexo 1) poderíamos observar a extensão territorial dos aldeamentos da Bahia e a situação jurídica de suas terras dos mesmos, caso as informações fossem apresentadas para todos os aldeamentos. Contudo, apenas para alguns aldeamentos são apresentadas as referidas informações de forma satisfatória. Com relação à maior parte deles, as informações são incompletas.

Com referência aos aldeamentos de Ilhéus, as informações são ainda mais imprecisas, pois apenas sobre os aldeamentos de Catolés e Barra do Salgado existe a informação de que suas terras não são demarcadas; sobre os demais, existe somente a informação de que se ignora a extensão. Prevalecia, portanto, certa negligência com relação à transmissão de informações dos missionários e autoridades de Ilhéus, acerca dos aldeamentos, para a capital da província. Telma Moreira de Souza observa que o Visconde de Sergimirim, quando assumiu o cargo de Diretor 
Geral dos Índios, reclamou ao presidente da província as dificuldades para elaboração do seu relatório, porque os diretores não enviavam informações das aldeias que administravam ${ }^{25}$.

No anexo 1 é apresentado o quadro das aldeias da Província da Bahia de 1855, onde se pode observar a preocupação provincial acerca das seguintes informações: o nome da comarca, o nome do aldeamento, número de índios dos aldeamentos, estado de "civilização" dos mesmos, nome do missionário que os dirigia, vencimento recebido pelos missionários, a extensão territorial do aldeamento, bem como um campo para as observações acerca de cada aldeamento. Note-se, além disso, que todas as observações são referentes à situação das terras dos aldeamentos. Na coluna observações, a situação das terras dos aldeamentos é apresentada de forma heterogênea, tanto em relação à extensão ocupada quanto em relação à situação administrativa das terras. Em muitos aldeamentos a extensão territorial é ignorada ou não registrada, e em outros as terras aparecem como sendo exploradas pelas Câmaras e arrendadas. Há ainda o registro de aldeamento em terras particulares. Tal heterogeneidade reflete a complexa teia estabelecida para a conquista e territorialização dos indígenas, desde finais do século XVIII, e que vai se delinear de forma mais coesa a partir das legislações editadas em meados do XIX, a saber, o engendramento dos interesses de aldeamento de catequese e a civilização dos índios para

25 SOUZA, Telma Moreira de. Entre a cruz e o trabalho: a exploração da mão de obra indígena no sul da Bahia (1845-1875). Dissertação de Mestrado. UFBA, 2007, p. 130. 
fins da colonização e expansão territorial do Império do Brasil $^{26}$.

Ao estabelecer uma aproximação das informações sobre a situação territorial dos aldeamentos da província do quadro 1, de 1855 (ver anexo 1), com as informações do quadro 2 de 1861 (ver anexo 2), mais especificamente o quesito pretensão de terras, pode-se obter dados importantes sobre a exploração agrícola dos aldeamentos. Esse quesito apresenta informações sobre terras cultivadas e com gênero de cultura e terras não cultivadas pelos índios, e a partir disso podemos inferir acerca da atuação indígena na atividade da agricultura, bem como sobre a possibilidade do cultivo agrícola em território de aldeamento por não índios. Como existia um percentual de terras não cultivadas por índios, isso leva a crer que nas terras do aldeamento coabitavam índios e não índios, uma estratégia da política indigenista para fins da "assimilação". No entanto, essa estratégia da mistura aparentemente não ocorreu em São Pedro de Alcântara, pois não encontramos informações que nos permitem afirmar que ali ingressaram não índios para cultivar terras. Apesar disso, explicitaremos, ao longo do trabalho, com base em outros registros documentais, que a relação entre índios e não índios foi muito estreita em Cachoeira de Itabuna, embora os não índios não vivessem dentro do perímetro do aldeamento.

26 Ocupados em discutir os meandros e engendramentos da política indigenista imperial, podemos destacar: CUNHA, Manuela Carneiro da. "Política indigenista no século XIX". In: CUNHA, Manuela Carneiro da (Org.). História dos índios no Brasil. São Paulo: FAPESP, Companhia das Letras, 1992; MOREIRA NETO, Carlos de Araújo. Os índios e a ordem imperial. Brasília: CGDOC-FUNAI, 2005; SAMPAIO, Patrícia Melo. "Política indigenista no Brasil imperial". In: GRINBERG, Keila; SALLES, Ricardo (Orgs.). O Brasil Imperial, volume I: 1808-1831. Rio de Janeiro: Civilização Brasileira, 2009; SAMPAIO, Patrícia Melo. Espelhos partidos: etnia, legislação e desigualdade na Colônia. Manaus: Editora da Universidade Federal do Amazonas, 2011. 
No quadro1 (anexo 1), a situação territorial dos aldeamentos não está bem definida, visto que não traz informação sobre a extensão territorial de alguns deles. Sobre a situação jurídica de suas terras, podemos identificar informações precisas sobre alguns deles, como já explicitamos acima. No Quadro 2 (Anexo 2), contudo, podemos suscitar duas questões, a nosso ver pertinentes para se pensar os problemas de catequese, civilização, colonização e ocupação territorial. A primeira refere-se à demonstração acerca das terras indígenas cultivadas por diversos e as não cultivadas por índios. Embora não se apresente dados de forma clara para todos os aldeamentos, é importante questionar o que significava dizer terras cultivadas com diversos. Os índios aldeados participavam ativamente da economia regional, atuando em uma agricultura comercial e diversificada? A segunda questão diz respeito às terras não cultivadas pelos índios, pois isso sugere que os aldeamentos podiam ser um espaço complexo no que toca às relações estabelecidas entre diferentes sujeitos étnicos e sociais.

As questões levantadas não permitem respostas rápidas e imediatas, pois as informações apresentadas nos quadros aqui analisados são insuficientes para isso. $O$ objetivo é apenas suscitar essas questões, que serão retomadas e discutidas com o apoio de outras fontes ao longo do trabalho. O que já podemos inferir é que os homens e as mulheres em "situação de aldeamento" foram sujeitos ativos no processo histórico e participavam da economia regional, pois, como bem frisa Marcelo Henrique Dias em seu estudo $A$ inserção econômica dos aldeamentos jesuíticos 
na capitania de Ilhéus ${ }^{27}$, esta população participava de forma efetiva na produção e circulação de mercadorias, num processo que envolvia toda a capitania. Tal assertiva de Dias refere-se ao mundo colonial, e não pode ser transportada para a atuação dos indígenas aldeados do século XIX de forma automática. Contudo, permite afirmar que a atuação dos índios na dinâmica da produção agrícola para fins de abastecimento e comércio não era uma situação estranha para as populações aldeadas da região.

Na fala do Presidente da Província João Maurício Wanderley, na abertura da Assembleia Legislativa da Bahia, de 1853, registra-se a seguinte informação:

[...] S. Pedro d'Alcantara, situado à margem septentrional do Rio Cachoeira, 12 legoas acima da Villa de Ilhéos [...]. Esta aldêa tem hoje por missionario e director Fr. Vicente de Ascoles dotado de muita energia que tem chamado os índios ao trabalho com perseverança, fazendo-os plantar mais de vinte mil pés de café e vinte mil de cacao, e produzir farinha, arroz e feijão bastante para alimentação das 38 famílias da tribu Camacan, que ali há com 196 indivíduos. ${ }^{28}$

O fragmento citado demonstra que, a exemplo do que acontecia no tempo dos jesuítas, estudado por Dias, os índios dos aldeamentos da Bahia oitocentista, em particular do sul da Bahia, eram sujeitos ativos e

27 DIAS, Marcelo Henrique. “A inserção econômica dos aldeamentos jesuíticos na capitania de Ilhéus". In: Um lugar na história: a capitania e comarca de Ilhéus antes do cacau. CARRARA, Ângelo Alves; DIAS, Marcelo Henrique (Orgs.). Ilhéus: Editus, 2007b, p. 230.

28 Fala que recitou o presidente da Província da Bahia, João Maurício Wanderley, $1^{\circ}$ de março de 1853, p. 35. In: Relatórios Provinciais Presidenciais (18301930). Disponível em: <http: / / www.crl.edu/brazil/provincial/bahia>. 
sua mão de obra importante na economia do café e do cacau, funcionando como parte integrante do motor de desenvolvimento econômico da região. Difícil pensar que os índios plantavam para a subsistência apenas, quando a documentação menciona uma produção agrícola vasta e de proporções consideráveis. Além do mais, deve-se levar em consideração a característica histórica da capitania de Ilhéus, fornecedora de produtos para o comércio entre a capitania, a capital e o Recôncavo ${ }^{29}$, e a proeminência da atuação indígena nesse processo.

\subsection{Ocupação e exploração territorial: a instalação do aldeamento São Pedro de Alcântara, em Ferradas}

Antes de discutirmos a fundação do aldeamento São Pedro de Alcântara, se faz necessário pontuar a existência de dois núcleos distintos de povoamento naquela região: o núcleo de Ferradas, de população indígena aldeada, e o de Cachoeira de Itabuna, que em meados do século XIX era composto por migrantes, sobretudo sergipanos. Percebemos, nesse encontro entre índios e não índios, diversas facetas da situação de fronteira, na qual se encontravam os aldeados de Ferradas, fazendeiros, botocudos requerentes de aldeamento, botocudos, noc-noc que impunham resistência aos empreendimentos da colonização, o missionário e autoridades governamentais ${ }^{30}$.

29 DIAS, Marcelo Henrique. Op., cit., 2007b, p. 114-115.

30 No escopo do aparato teórico que trata do conceito de fronteira, destacamos neste estudo: João Pacheco de Oliveira (1998), Maria Regina Celestino de Almeida (2001; 2013) e Vânia Losada Moreira (2010; 2011), que trataram da questão da construção de fronteiras étnicas no mundo territorializado. Nesse bojo de reflexão teórica sobre fronteira, são fundamentais os direcionamentos teóricos de Frederik Barth, 2011: Grupos étnicos e suas fronteiras, como referência fundamental para pensar a ideia de fronteira étnica entre os grupos sociais em situação de contato. 
E por fronteira deve-se entender, tal como explica Laura Muñoz, um espaço de encontro entre o mundo dos índios e o mundo dos colonizadores. A autora, que trata o processo de colonização do Caribe e as diversas fronteiras estabelecidas, define fronteira como o "espaço onde [os] dois mundos se tocavam pela colonização [...], pelo intercâmbio [...], seu caráter de fronteira excedeu o de uma linha divisória e se converteu, melhor, em uma área ampla, variável e complexa, de contatos, cruzes e mesclas". ${ }^{31}$ Tais fronteiras eram, além disso, fluidas, intercambiáveis.

$\mathrm{Na}$ introdução de Espacios de interacción en las tierras bajas del sur de América, Nacuzzi pontua a proposta de apresentar os espaços de fronteira colonial sul-americano em seus termos geográficos, sem, contudo, desmerecer a importância de se perceber a fronteira como espaço de contato entre os sujeitos. Para Nacuzzi, se hoje temos os estudos sobre fronteira desenhados como espaço de atuação dos grupos e sujeitos, não se deve perder de vista que tais espaços de fronteira foram estabelecidos inicialmente pelo colonizador: "lós que eligieron o determinaron los lugares donde estabelecieron fuertes, misiones o ciudades [...], eligieron los lugares del contacto, o por lo menos, tomaron las primeras iniciativas para que algunas fronteras se crearan donde se crearon" ${ }^{\prime 2}$. Ou seja, na perspectiva da autora, é importante não abandonar a noção de limite delineada no processo de colonização, porque essa noção permitiu que se delineasse também

31 MUÑOZ, Laura. "Bajo el cielo ardiente de los trópicos: Las fronteras del Caribe em el siglo XIX”. In: Fronteiras: Paisagens, personagens, identidades. GUTIÉRREZ, Horácio; NAXARA, Márcia R. C. e LOPES, Maria Aparecida de S. (Orgs.). Franca: ENESP, São Paulo: Olho d'Água, 2003, p. 55.

32 NACUZZI, Lidia R. "Introdução". In: LUCAIOLI, Carina; NACUZZI, Lidia. (Orgs.). Espacios de interacción en las tierras bajas del sur de América. Buenos Aires: Sociedad Argentina de Antropologia, 2010, p. 12. 
a zona de contato dos espaços de sociabilidade e de trânsito. Em outras palavras, a partir da noção de fronteira geográfica, que separa, limita e, ao mesmo tempo, se constitui do contato e ação de pessoas, grupos, e povos, foi possível construir a noção de fronteira enquanto espaço da interação destas pessoas, povos, e suas culturas. A fronteira, portanto, é entendida como "espaço transicional" permeado de conflitos, interações, estratégias, negociações, ressignificações.

A ideia de Nacuzzi condensa, em certa medida, os contornos dos capítulos II e III do nosso trabalho, onde demonstraremos que a ideia de limite da fronteira, delineada pelos propósitos da colonização, visa demarcar territórios, avançar e conquistar sertões. Nos referidos capítulos, nossa preocupação central é situar o processo de territorialização de populações indígenas no sul da Bahia, criação dos diferentes espaços da atuação colonizadora - Ferradas e Cachoeira de Itabuna - naquela parte da região, e as relações estabelecidas entre os atores sociais.

Também pretendemos, ao longo deste estudo, demonstrar que a paisagem do delineamento geográfico da conquista, ou seja, o de ocupação dos espaços fronteiriços e exploráveis foi, aos poucos, modificada pelas relações cotidianas estabelecidas entre os diferentes atores envolvidos no projeto colonizador. A fronteira perdeu seu caráter geográfico inicial e se converteu em espaço de intercâmbios, trânsitos e fluidez.

Em 1814, foi fundado o núcleo indígena São Pedro de Alcântara, que ficaria conhecido também como aldeamento de Ferradas e atuaria de forma decisiva na ocupação territorial da região, atendendo a uma política de colonização nos termos dos interesses do período colonial e, subsequentemente, imperial. Vale ressaltar que, nos moldes de São Pedro de Alcântara, muitos outros aldeamentos foram 
instalados no sul da Bahia ao longo do século XIX, com o intuito de tornar transitável e explorável o território que compreendia, principalmente, a região dos rios Cachoeira ou Colônia e Pardo. Note-se, além disso, que os aldeamentos instalados naquela região formavam um corredor entre Ilhéus e Conquista (vide mapa abaixo).

FIGURA 1 - Aldeamentos do sul da Bahia

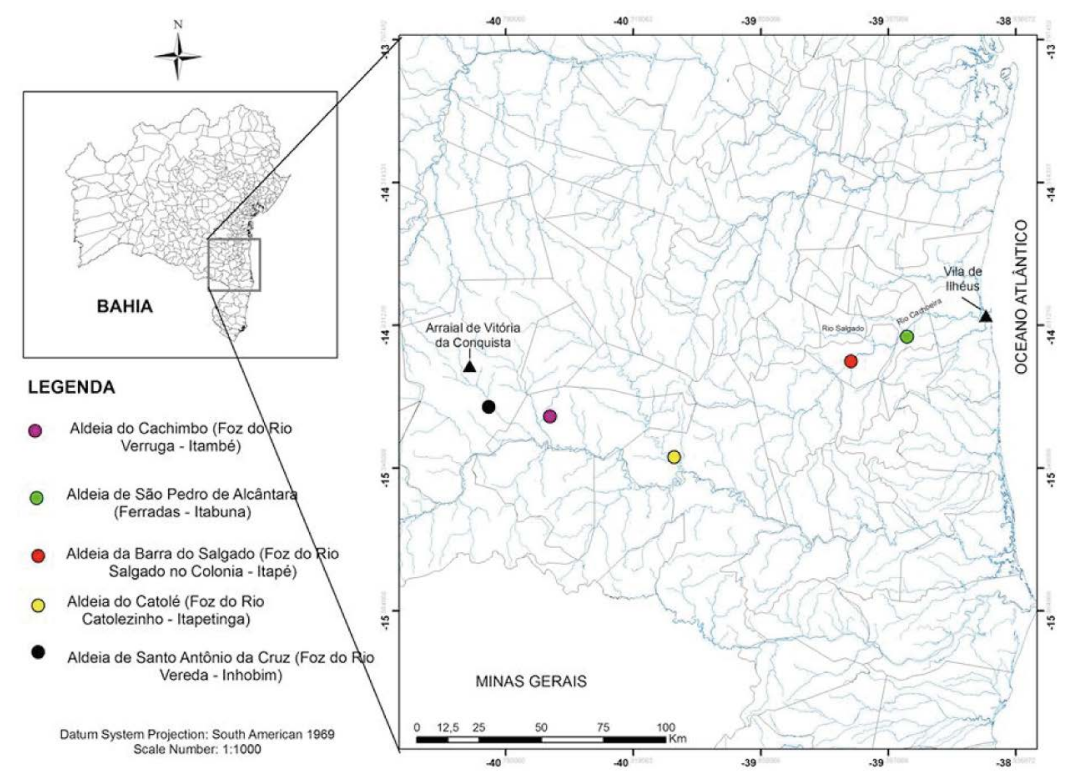

Fonte: Mapa confeccionado por Girleney Araújo, para a presente pesquisa.

Nessa perspectiva de fundação de núcleos de povoamento por meio da criação de aldeamentos de catequese, se consolidará, na região do rio Cachoeira, o núcleo de migrantes denominado de Cachoeira de Itabuna, que hoje corresponde à atual cidade de Itabuna. As informações sobre esse núcleo de povoamento são escassas. A documentação que trata do aldeamento e as escrituras dos livros de notas da vila de Ilhéus fazem menções corriqueiras ao núcleo Cachoeira de Itabuna, visto que, na primeira déca- 
da do século XIX, já se comprava e vendia terras no núcleo denominado de Cachoeira de Itabuna e, nos registros paroquiais da década de 1850, são registradas as terras da Cachoeira de Itabuna, mas não nos oferecem maiores informações. Sendo assim, nos restam as observações de João da Silva Campos, trabalho cuja primeira edição corresponde a $1947^{33}$. Ainda que o autor nem sempre identifique as fontes apresentadas, sua obra se configura como uma importante contribuição para a história de Ilhéus e se constitui numa referência de citação quase obrigatória para os estudos regionais, sobretudo pela importante compilação de documentos sobre o sul da Bahia, que abrange um amplo marco temporal.

João da Silva Campos observa que, em 1818, o estrangeiro Pedro Weyll e outro companheiro haviam adquirido terrenos à margem esquerda do rio Cachoeira, iniciando, assim, a colonização estrangeira em Ilhéus. Segundo Campos, naquela localidade, os alemães teriam formado a colônia de São Jorge da Cachoeira de Itabuna, composta de "28 casais com 161 indivíduos," que teriam chegado à região alguns anos depois do estabelecimento de Pedro Weyll naquela localidade. Contudo, diante das dificuldades em manter a colônia em funcionamento, ela não vingou. Uma segunda leva de imigrante foi destinada à colônia, no ano de 1823, e teve o socorro dos cofres da Assembleia Geral, com uma verba de $4.384 \$ 300$ réis. $^{34}$

33 Muito embora a data da primeira edição do livro Crônica da Capitania de São Jorge dos Ilhéus conste do ano de 1947, ele foi escrito na década de 1930 por encomenda do então intendente de Ilhéus Eusínio Lavigne, como nos lembra Marcelo Dias na introdução de sua tese de doutoramento: DIAS, Marcelo Henrique. Economia, sociedade e paisagens da Capitania e Comarca de Ilhéus no período colonial. Tese. UFF, Niterói-RJ: 2007a.

34 CAMPOS, João da Silva. Op., cit., p. 323-324. 
As informações trazidas por Silva Campos confirmam a existência do núcleo Cachoeira de Itabuna já nas primeiras décadas do século XIX. Ele cita o ano de 1818, contudo nossa documentação registra um processo de compra e venda de terras em Cachoeira de Itabuna já em 1814 (p.160). A disparidade das datas entre as informações colhidas na documentação levantada e a menção do núcleo por Campos se devem, provavelmente, a certa incongruência de datas e informações presentes em sua obra. De certo, Weyll e outros estrangeiros desempenharam papel importante na história da ocupação territorial e exploração do trabalho indígena na região, como veremos mais adiante. Por ora, importa observar que aquele núcleo de povoamento foi fundado nas primeiras décadas do século XIX e a existência de comercialização de terras em Cachoeira de Itabuna segue por toda a primeira metade do Oitocentos.

O mesmo Silva Campos, referindo-se novamente à Cachoeira de Itabuna, utiliza informações do Almanak de Itabuna, e menciona que, por volta de 1860 , teria começado a ser povoado aquele núcleo, onde seria erguida a cidade de Itabuna. Entendemos, contudo, que aquela colônia falida na década de 1820 pode ter tido suas terras ocupadas por aqueles que ali permaneceram com suas posses, e, talvez, enfrentado estágios de despovoamento, já que a colonização daquela região enfrentaria, por todo o século XIX, a presença resistente de populações indígenas. Dessa forma, faria sentido o registro do [re] povoamento de Cachoeira de Itabuna em meados do século XIX por migrantes nacionais. Campos enfatiza que:

[...] sendo os seus primeiros moradores quase todos sergipanos. Em princípio de 1861 já a câmara de Ilhéus pedia a criação de um distrito policial em Cachoeira de Itabuna, zona onde existia grande população, não 
somente de naturais do município, como do centro e do norte da província, e de Sergipe, que para ali afluíam desde alguns anos atrás, abrindo roças e fazendas ${ }^{35}$.

A data de criação do núcleo dada pelo autor é imprecisa, mas as escrituras dos livros de notas, bem como os Registros Paroquiais de Terras (1857-1862) da vila de Ilhéus e as correspondências testemunham a existência do núcleo num período anterior ao exposto por Silva Campos. Inferimos, a partir do acompanhamento das fontes, que o núcleo não deixou de existir após a falência da colônia estrangeira ou da tentativa de manutenção da mesma; os colonos que ali se estabeleceram permaneceram e aumentaram suas posses, visto que, algumas décadas mais tarde, Cachoeira de Itabuna, posteriormente denominada de Tabocas, se constituirá de pequenas fazendas de cacau, como observa Fernando de Staiger em correspondência acerca das obras na estrada Ilhéus-Conquista, em $1868 .^{36}$

Contudo, o trabalho de Silva Campos fornece pistas importantes sobre a fundação do povoado. Ele nos permite perceber os delineamentos da ocupação territorial daquela região com foco na relevância da atuação do aldeamento de Ferradas para o cumprimento do projeto colonizador. O próprio Silva Campos menciona que, por ocasião da chegada dos migrantes nortistas, eles "procuravam a parte mais cultivada do município de Ilhéus que era às margens do rio Cachoeira, localizando-se até a aldeia de Ferradas" ${ }^{37}$. A fala de Silva Campos pode ser corroborada

35 CAMPOS, João da Silva. Op., cit., p. 380.

36 APEB: Seção Arquivo Colonial e Provincial; série Justiça-correspondências juízes de Ilhéus; maço 2401; ano 1868, fl. 8.

37 CAMPOS, João da Silva. Op., cit., p. 391. 
com o testemunho do juiz de direito de Ilhéus, Antônio Villaça, que em 22 de julho de 1868 escreveu ao presidente da província, José Bonifácio Nascimento, esclarecendo que os migrantes destinados à colônia de Comandatuba deveriam devolver o valor empregado pelo governo com suas passagens, visto que, ao chegarem à região, "mudaram de resolução, e pretendem estabelecer-se em lavoura no Rio Cachoeira de Itabuna, onde encontraram alguns parentes, que vivem da lavoura". ${ }^{38}$

Os estudos regionais apontam para a importância dos aldeamentos no processo de ocupação territorial na região, a exemplo de Freitas e Paraíso, que afirmaram, em seu estudo, que no processo colonizador em Ilhéus, a preferência recaía sobre as áreas de aldeamentos ${ }^{39}$; também as observações acerca das escrituras de compra e venda de terras nos permitem perceber, ao longo do século, o crescente movimento de ocupação e exploração territorial, com a formação de plantações e fazendas de cacau. Podemos inferir, portanto, que aqueles núcleos, isto é, Cachoeira de Itabuna e Ferradas, embora fossem núcleos distintos, estavam totalmente correlacionados. Mostra disso é a fala do juiz de órfãos de Ilhéus:

[...] Havendo a tribu noc-noc pelos botocudos continuado suas incursões sobre as Ferradas e passando destas para baixo ameaçando já os fazendeiros de Cachoeira de Itabuna, julguei que devia aproveitar os apresentados [botocudos que requeriam aldear-se] e seu guia para unidos com alguns

38 APEB: Seção Colonial e Provincial; série Justiça-correspondências juízes de Ilhéus; maço 2401; ano 1868.

39 FREITAS Antônio Guerreiro de; PARAISO, Maria Hilda Baqueiro. Op., cit., p. 65. 
Camacans sob a direção do reverendo Missionário [...] entrarem nas mattas a ver se podiam conseguir o aldeaimento daquella tribu assim nocivo ${ }^{40}$.

O núcleo indígena e o núcleo de nacionais eram próximos o suficiente para que os ataques dos noc-noc a Ferradas logo tivessem alcançado Cachoeira de Itabuna. Dentre outros papéis, Ferradas desempenhava o de garantir a segurança dos fazendeiros de Cachoeira de Itabuna. Notase que a preocupação central do juiz e delegado Antônio D'Aguiar Silva é com a segurança dos fazendeiros, que os Camacãs de Ferradas, juntamente com botocudos apresentados ao frade Ludovico, tinham a tarefa de garantir.

A fundação do aldeamento São Pedro de Alcântara ou Ferradas deve ser analisado pela perspectiva da política indigenista da virada do século XVIII para o XIX, que visava atender à demanda colonial de conquista dos sertões, de colonização e garantia da mão de obra para os serviços públicos e particulares ${ }^{41}$. Nesse contexto, o significado empregado para a palavra "sertão" revela a positivação do sentido da conquista, visto que conquistar os sertões significava levar a "civilização" para as áreas ainda não ocupadas e exploradas pelo governo colonial e, subsequentemente, imperial. Nas palavras de Vânia Moreira, “[...] o sertão era, em primeiro lugar, o oposto do mundo policiado, pois não se assemelhava à 'civilização' e nem

40 APEB: Seção Arquivo Colonial e Provincial; série Justiça-correspondências juízes de Ilhéus; maço 2395-I; 1843.

41 Sobre as políticas indigenistas voltadas a atender o projeto de colonização e captação de mão de obra indígena, ver: MOREIRA NETO, Carlos de Araújo (2005); SAMPAIO, Patrícia melo (2009, 2011); CUNHA, Manuela Carneiro da. (1992); ALMEIDA, Maria Regina Celestino de. (2013); MOREIRA, Vânia Losada (2010). 
tampouco estava sob a jurisdição política da monarquia portuguesa e do "bom governo"42.

$\mathrm{Na}$ área da Comarca de Ilhéus, o projeto de conquista das regiões interioranas esbarrava na resistência, em certo grau, dos Camacãs, e em maior intensidade dos Pataxós e, sobretudo, dos botocudos, populações que eram, historicamente, as legítimas donas daqueles territórios. Segundo a bibliografia regional especializada, "os índios continuavam a ser apontados como o obstáculo mais difícil de ser superado na concretização dos empreendimentos de conquista, colonização e abertura de estradas" ${ }^{\prime 3}$, o que tentava justificar as medidas para "conquistar" ou "desinfetar" os sertões. O testemunho do capitão-mor Antônio Dias de Miranda, membro da família Gonçalves da Costa, cuja atuação provocou intensos conflitos com as populações indígenas da região, como já mencionamos, é elucidativo quanto às práticas contraditórias do governo local acerca das políticas adotadas para os Camacãs, Pataxós e botocudos, habitantes do sul da Bahia. Garantir a civilização significava conquistar os sertões, aldear os índios e até mesmo expulsá-los dos territórios a serem ocupados. Nas palavras de John Monteiro, "atrair ou repelir, civilizar ou exterminar [...]. A noção de civilização, ao que parece, abrigava os dois extremos." ${ }^{44}$

42 MOREIRA, Vânia Maria Losada. "Entre as vilas e os sertões: trânsitos indígenas e transculturações nas fronteiras do Espírito Santo (1798-1840)", Nuevo Mundo, Mundos Nuevos [Online], Debates, posto on-line no dia 31 janeiro 2011. Acesso em: 8 mar. 2014. Disponível em: <http:/ / nuevomundo. revues.org/60746>. DOI: 10.4000/nuevomundo. 60746, p. 1.

43 FREITAS, Antônio Guerreiro de; PARAÍSO, Maria Hilda Baqueiro. Op. Cit., p.50.

44 MONTEIRO, John Manuel. Tupis, Tapuias e historiadores: Estudos de História Indígena e do Indigenismo. Tese de livre docência. Unicamp: Campinas, 2001, p. 143. 
Antônio Dias de Miranda, em 26 de dezembro de 1826 , se reporta ao presidente da província lembrando que sua família historicamente atuava naquela região, na altura do Rio Pardo. Informava que as patentes militares recebidas pelos homens de sua família eram em merecimento pelo árduo trabalho de conquista dos sertões, prestado ao governo, bem como pelas despesas financeiras assumidas por eles para tal fim:

Antonio Dias de Miranda, capitão mor da conquista do certão da ressaca, reprezenta a V. Excia. que tendo sido a mesma conquista concluída acusta das fadigas, e dispezas de seu avo, e finado pai João Gonçalvez da Costa (...), aquelles habitantes da conquista costumados a empreheinderem grandes emprezas contra os índios, Mongoiós, Patachó, e Botocudos, q' os costumavão invadir, não podem levar a bem o serem chamados, para outro qualquer serviço, q' não seja, o de domarem, ou ao menos afugentarem os ditos índios, para civilisação, e augmento da sobredita conquista, no que muito se tem o suplicante empenhado, não se poupando por sy, e seus parentes, a todas as despezas, fadigas, e perigo de vida ${ }^{45}$.

$\mathrm{Na}$ fala de Antonio Dias de Miranda fica expresso que a estratégia de aldear os Camacãs, Pataxós e Botocudos da referida região não era a única existente. Quando se tornava difícil conseguir o aldeamento das populações, a estratégia adotada era bem diferente e recaía na expulsão dos mesmos de suas terras. Isso nos permite vislumbrar as tensões, os conflitos e as complexidades nas

45 APEB; seção Arquivo Colonial e Provincial; série Agricultura; maço 4613; ano 1826. 
relações entre colonizadores e indígenas no sul da Bahia oitocentista. Vale ressaltar, no entanto, que no conjunto da documentação analisada, a estratégia predominante durante o século XIX é a de estabelecimento de aldeamentos de catequese na região, em lugar da mera expulsão dos índios dos territórios sul baianos.

A história sobre a instalação do aldeamento São Pedro de Alcântara, em Ferradas, até bem pouco tempo atrás era bastante controversa. Freitas e Paraíso, em Caminhos ao encontro do mundo: a capitania, os frutos de ouro e a princesa do sul, frisam como figura central no processo de criação do aldeamento o Capitão-mor João Gonçalves da Costa. A monografia de Cordeiro ${ }^{46}$ versa acerca da atuação capuchinha na Comarca de Ilhéus e traz algumas informações sobre a chegada de Frei Ludovico de Livorno (Liorne) àquela localidade, mas revela pouco acerca do envolvimento do missionário no processo de fundação e desenvolvimento do aldeamento.

Segundo Freitas e Paraíso, ${ }^{47}$ os indígenas de São Pedro de Alcântara foram aldeados pela família de Gonçalves da Costa, e é importante frisar que, historicamente, essa família atuou no combate aos índios resistentes ao processo colonizador daquela região. Em Os Botocudos e sua trajetória histórica, Paraíso destaca que o estopim para a deflagração da guerra justa contra os "Botocudos", no sul da Bahia, teria ocorrido pela concessão de uma sesmaria à família do capitão-mor na região de Vitória da Conquista, então, vila Imperial da Vitória, quando os índios reagiram à construção de um corredor de comércio entre a região e

46 ANDRADE, João Cordeiro. Missões Capuchinhas na Comarca de São Jorge dos Ilhéus (1816-1875). Monografia. Ilhéus, UESC, 2003.

47 FREITAS, Antônio Guerreiro de; PARAÍSO, Maria Hilda Baqueiro. Op., cit., p. 53. 
Minas. A autora salienta, além disso, que a família de Gonçalves da Costa implantou a pecuária na região e, nesse sentido, era do seu interesse manter as vias de acesso aos comerciantes e às suas tropas ${ }^{48}$.

Contudo, mais recentemente, Teresinha Marcis, em sua tese de doutoramento, nos apresenta informações valiosas e mapeia a trajetória histórica que levaria à instalação do Aldeamento São Pedro de Alcântara, baseando sua pesquisa em informações colhidas no Arquivo Nacional da Torre do Tombo, bem como em fontes do Arquivo Histórico Ultramarino. Conforme a sólida reflexão de Marcis, a criação do aldeamento São Pedro de Alcântara está relacionado ao antigo aldeamento instalado às margens do rio Almada, que teria sido extinto, e os índios restantes transferidos para Ferradas. $\mathrm{Na}$ nova localidade, os índios foram aldeados juntamente com índios camacãs, que habitavam a referida região e que, com a abertura da estrada Ilhéus-Conquista, foram "descidos" para o aldeamento. Provavelmente, os Camacãs foram aldeados perto da estrada para garantir o sucesso do empreendimento, que poderia dispor, a partir de então, da mão de obra dos índios para sua conservação. Fundou-se, assim, em 1814, o aldeamento São Pedro de Alcântara ${ }^{49}$.

Teresinha Marcis recompõe, de forma muito interessante, a trajetória estabelecida entre o aldeamento de Nossa Senhora dos Índios Gréns do rio Almada e a instalação do novo empreendimento colonial em Ferradas, observando, no bojo desse processo, a atuação do então Ouvidor da Comarca, Balthazar da Silva Lisboa. A partir das informações colhidas pela pesquisa de Marcis, podemos traçar a teia de interesses relacionada à transferência dos

48 PARAÍSO, Maria Hilda Baqueiro. 1992, Op., cit., 1992, p. 416-417.

49 MARCIS, Teresinha. Op., cit., p. 241-246. 
aldeados do Almada para Ferradas. O pano de fundo é o suposto interesse do Ouvidor no beneficiamento de terras que supomos pertencerem a ele, pois foram compradas por Balthazar naquela região, algum tempo antes da instalação do novo aldeamento, conforme escritura de terra de $1814^{50}$. As informações de que dispomos não permitem afirmações conclusivas, mas tudo sugere uma sobreposição das terras compradas por Balthazar da Silva Lisboa e das terras destinadas ao aldeamento de Ferradas.

Na trajetória da extinção da Aldeia de Nossa Senhora dos Indios Gréns, localizada em Almada, e de instalação do aldeamento de Ferradas, a figura de Balthazar da Silva Lisboa é emblemática e central. Teresinha Marcis observa, na documentação compulsada, as contradições presentes nas medidas adotadas pelo ouvidor com relação ao aldeamento do Almada. Primeiramente, o pároco responsável pela freguesia, Francisco dos Santos Solledade, enviou requerimento, em 1796, ao Secretário de Estado dos Negócios Estrangeiros e de Guerra solicitando a extinção da aldeia devido à incapacidade de civilização dos Gréns, ali aldeados. Além disso, diante da cobrança da Mesa de Consciência e Ordem de esclarecimentos sobre o assunto, o Ouvidor da Comarca, Balthazar da Silva Lisboa, emitiu um parecer favorável à extinção do aldeamento.

No entanto, ressalta Marcis, quase imediatamente após o ocorrido, isto é, um mês depois, o ouvidor remeteu ao arcebispo da Bahia outro parecer, em que refutava todas as justificativas utilizadas pelo padre da freguesia para a extinção do aldeamento e defendeu a sua permanência. "O ouvidor concluía a defesa da manutenção da freguesia apelando para a história dos gréns, reforçando

50 APEB: Livros de Notas da Vila de Ilhéus; livro 5; ano 1814; folhas 39-40. 
a necessária proteção aos indígenas por honra da Igreja e do Estado." 51 Ainda ressalta a autora que o aldeamento e freguesia de Nossa Senhora dos Indios Gréns existiu no Almada até 1814, quando da sua extinção definitiva pelo mesmo ouvidor Lisboa, que outrora havia se colocado ferrenhamente contrário ao seu esfacelamento ${ }^{52}$.

Nesta ocasião, como já mencionamos anteriormente, estava em prática no sul da Bahia o projeto de abertura da estrada que seguia o curso dos rios Salgado e Cachoeira, tendo os índios habitantes daquela região, os camacãs, "aceitado" se estabelecer no aldeamento de Ferradas depois de um processo de resistência ${ }^{53}$. O interesse em aldeá-los recaía sobre a necessidade de mão de obra para trabalhar na estrada e possibilitar o trânsito na região. Sendo assim, os gréns do Almada teriam sido transferidos por Lisboa para o aldeamento São Pedro de Alcântara para dar suporte ao novo empreendimento colonial.

A documentação deixa bastante em evidência o papel decisivo do ouvidor Lisboa no esfacelamento do aldeamento do Almada e na instalação do novo aldeamento de Ferradas. Importa pensar sobre o interesse dessa autoridade colonial no engendramento de um processo, no mínimo, controverso. Desse modo, para construir a nossa argumentação sobre a teia de interesses, que pode servir como pano de fundo para entender as obscuras decisões do ouvidor concernentes à situação do aldeamento do Almada, vamos explorar a sugestiva e bastante elucidativa escritura de compra de terras no rio Cachoeira, efetuada pelo mesmo ouvidor Lisboa, em 1814.

51 MARCIS, Teresinha. Op., cit., p. 245.

52 Idem, p. 246.

53 Idem, ibidem 
Saibão quantos este publico Instrumento de escriptura de Venda de uma sorte de terras [...] no anno do Nascimento de Nosso Senhor Jesus Christo de mil oito centos e quatorze aos oito dias do mês de maio do dito anno nesta Villa de São Jorge Cabeça da Comarca dos Ilhéos caza de rezidencia do Doutor Desembargador Ouvidor desta Comarca Balthazar da Silva Lisboa [...] de uma parte como vendedor Francisco Soares da outra Balthazar da Silva Lisboa [...] dito vendedor [...] que elle pelo poder especial que tenha de sua procuração bastante passada pelo seu irmão, o Reverendo Ignacio Luiz Gonzaga de Essa vendia como de facto vendido tenha de hoje para todo o sempre huma sorte de terras ditas no Rio da Cachoeira de Itabuna [...] ao dito Senhor Doutor Balthazar da Silva Lisboa, pelo presso e quantia de quatrocentos mil réis, [...] cuja sorte de terra disse elle comprador as comprava para o Excelentíssimo Antonio de Araujo Azevedo morador da Corte do Rio de Janeiro $[\ldots]^{54}$.

A postura dúbia de Balthazar com relação à situação do aldeamento do Almada, ora a favor da extinção, ora defendendo de forma veemente a permanência do mesmo, e depois partindo do próprio ouvidor a decisão de extingui-lo, nos permite pensar que as decisões tomadas pelo ouvidor e a habilidade com que as colocou em prática estavam ligadas aos interesses comerciais de Lisboa naquela área de Ilhéus, na qual se encontrava instalado o projeto de abertura da estrada para viabilizar o desenvolvimento da região. Tendo como testemunho a referida escritura, nossa hipótese é a de que o ouvidor estava de fato movido

54 APEB: Livros de Notas da Vila de Ilhéus; livro 5, Ano 1814, folhas 39-40. 
pelo interesse de promover a efetiva colonização daquela região e, mais ainda, por promover o beneficiamento das terras de Ferradas em benefício próprio, já que as terras, ou parte delas, pertenciam a ele mesmo.

Todo esse processo, observamos, portanto, que se dá no mesmo mês da transferência dos índios Gréns para o então aldeamento São Pedro de Alcântara. As terras foram compradas, segundo Lisboa, para um amigo do Rio de Janeiro, de quem não se tem mais notícias na documentação. Sobre essa nebulosa transação comercial, Silva Campos, quando cita em seu trabalho o processo de fundação do aldeamento de Ferradas, frisa dizer-se "algures que as terras de Ferradas pertenciam ao desembargador" ${ }^{\prime \prime}$. Desse modo, tudo indica que o ouvidor era o verdadeiro proprietário e beneficiado daquela transação e usou como intermediário, ou "testa de ferro", um amigo da Corte para justificar a compra das referidas terras.

Nossa hipótese, portanto, é que Lisboa tinha fortes interesses na extinção do aldeamento dos índios Gréns em Almada e na imediata instalação de um novo aldeamento às margens do rio Cachoeira. Sua atuação aparentemente contraditória esteve relacionada ao objetivo de tornar as terras de Ferradas beneficiáveis pela presença de um aldeamento que garantisse o seu acesso e aproveitamento econômico. Afinal, a região era habitada por populações resistentes ao processo de colonização, que precisavam ser conquistadas, pacificadas e aldeadas, e o próprio aldeamento garantia mão de obra indígena para o seu desenvolvimento inicial.

Como já foi mencionado, a parte sul da comarca suscitava interesse comercial, visto que se configurava

55 CAMPOS, João da Silva. Op., cit., p. 305. 
como um incipiente corredor de comércio entre Ilhéus, Conquista e Minas. A abertura da estrada Ilhéus-Conquista visava ligar Ilhéus e Conquista a outras regiões, a exemplo de Minas, visto que tornaria possível o trânsito de pessoas, tropas e mercadorias. Note-se, além disso, que no início do século XIX essa região é descrita, pela historiografia regional, como inabitada por colonos. Era uma região de índios que, com o decorrer do século, terminou por atrair o interesse dos imigrantes e regionais. Como evidenciam Freitas e Paraíso, a preferência desses imigrantes recaía sempre sobre áreas de atuação dos aldeamentos ${ }^{56}$. Portanto, tendo Balthazar comprado as terras localizadas no rio Cachoeira, e tudo nos leva a crer que se tratassem das terras de Ferradas, era vantajoso para ele manter aquela área habitada por índios aldeados que, por sua vez, coadjuvariam principalmente como mão de obra.

Nossa tese de que o aldeamento de Ferradas foi um empreendimento colonial diretamente relacionado aos interesses econômicos do ouvidor Lisboa é reforçada por sua estreita e contínua relação com Frei Ludovico de Livorno, primeiro missionário a administrar, como religioso e diretor, o aldeamento São Pedro de Alcântara. Explicitaremos esse argumento nas análises que compreenderão os próximos parágrafos deste capítulo, tendo como base os Annaes do Rio de Janeiro, tomo VI, no qual Balthazar da Silva Lisboa publica algumas cartas que the são dirigidas pelo Frei Ludovico. Nelas podemos extrair relevantes informações que, em contrapartida, reforçam a nossa ideia sobre os interesses que permeavam a ação do ouvidor acerca daquela região.

56 FREITAS, Antônio Guerreiro de; PARAÍSO, Maria Hilda Baqueiro. Op., cit., p. 65. 
Convém ressaltar que a estreita relação estabelecida entre o ouvidor Lisboa e o frade Ludovico era consonante ao próprio papel que o cargo de ouvidor lhe imputava, pois os ouvidores exerciam um papel tutelar sobre o patrimônio dos índios. Manuela Carneiro da Cunha frisa que, sendo os índios considerados incapazes de administrar seus próprios bens, ficava o Estado responsável, portanto, por seus cuidados, sobretudo com relação às terras dos aldeamentos, "incumbindo a princípio os ouvidores das comarcas [até 1832] [...] da administração dos bens das aldeias." ${ }^{57}$ O papel central dos ouvidores na administração dos bens dos índios é confirmado pelo estudo de Vânia Moreira que, ao pesquisar acerca da administração das terras dos índios de Nova Benavente, na capitania do Espírito Santo, observou a teia estabelecida entre os diretores escrivães e os ouvidores nos eventos de usurpação das terras dos índios, quando eles reclamam "à rainha que os portugueses estavam tomando 'toda a terra dos índios', com o apoio do diretor escrivão e, pior ainda, com o consentimento dos ouvidores." ${ }^{58}$ Nessa perspectiva, inferimos que Lisboa, aproveitando-se das prerrogativas do cargo exercido na comarca de Ilhéus, à época, visava assegurar interesses econômicos pessoais a respeito das terras e mão de obra indígena no processo de instalação do aldeamento de Ferradas, como bem demonstra a documentação.

57 CUNHA, Manuela Carneiro da. Op., cit., p. 148.

58 MOREIRA, Vânia Maria Losada. “Nós índios, índios nós senhores de nossas ações... Direito de domínio dos índios e cristandade em conflito (vila de Nova Benavente, Capitania do Espírito Santo, 1795-1798)". In: Em terras lusas: conflitos e fronteiras no Império Português. MOTTA, Márcia; SERRÃO, José Vicente e MACHADO, Marina (Orgs.). Vinhedo. Editora Horizonte, 2013, p. 282. 
Em correspondência do dia 12 de agosto de $1819^{59}$, Frei Ludovico dirige a Balthazar informações sobre o estado de "civilização" dos índios aldeados, bem como sobre o estado produtivo do aldeamento naquele momento. Cinco anos após seu estabelecimento, o aldeamento já contava com plantações de algodão e café, além de mandioca, informações que, segundo o próprio frade, haviam sido solicitadas por Lisboa. Vale ressaltar que, por essa ocasião, Balthazar da Silva Lisboa já não desempenhava o cargo público de ouvidor, visto que permaneceu na função de ouvidor e juiz conservador das matas da comarca de Ilhéus até 1818. Em outra carta, de 29 de outubro de $1820^{60}$, o frade capuchinho novamente respondia às solicitações do antigo ouvidor e a carta gira em torno dos mesmos assuntos da correspondência anteriormente citada.

$\mathrm{Na}$ carta datada de 21 de outubro de 1829, Frei Ludovico de Liorne dirige-se a Balthazar como se ele fosse o "dono" daquele estabelecimento, com as seguintes palavras e informações:

[...] Lhe dou as notícias que V. S. me pede, deste seu estabelecimento de S. Pedro d'Alcântara, que lhe custou tanto trabalho, e quase a vida. [...] A crise política, a ausência de V. S. reduzio problemática a estável permanência desta povoação, na certeza de que se eu faltára, estava tudo acabado. Esta dúvida desanimou os Indios na sua progressiva plantação de café e algodão, como já tinha principiado; e em quanto não houver mais sólida firmeza, vão tendo mão a vida, ocupando-se em serviços de machado, em

59 LISBOA, Balthazar da Silva. Annaes do Rio de Janeiro. Editora Leitura: Rio de Janeiro. Tomo VI. 1835, p. 207-209.

60 Idem, p. 209-211. 
manter as ditas plantas, em caça, em pesca, em cultivar mandioca, e outros vegetaes necessários ao humano sustento ${ }^{61}$.

A citação acima, de fragmentos da carta endereçada a Lisboa, nos permite, além de reforçar a tese de que aquelas terras poderiam pertencer, de fato, a Balthazar, conceber a ideia da presença indígena como estratégia imperiosa para o beneficiamento das terras, pois eles serviam como mão de obra na agricultura. Ressaltamos a atuação dos índios aldeados, principalmente nas lavouras do café e algodão, produtos que não faziam parte do rol de plantações, mas seriam apenas para o abastecimento interno do aldeamento. Fica patente no teor da carta, além disso, que informar o andamento das plantações de café e algodão era a principal preocupação do missionário, pois ele não se esqueceu de escrever que os índios estavam desanimados com a ausência de Lisboa, e se ocupavam mais em serviços da lavoura de subsistência, o que, por sua vez, parecia ser um assunto secundário na correspondência entre eles.

A última das cartas consultadas data de 10 de fevereiro de 1831, momento em que já se encontra avançada a obra da estrada Ilhéus-Conquista. Ela serve de apoio para realçar outro interesse, que permeava o aldeamento como empreendimento voltado ao beneficiamento das terras de Balthazar da Silva Lisboa e do sul da Bahia. Segundo frei Ludovico, o aldeamento estabelecido por Balthazar contribuía muito para o sucesso da estrada. De acordo com o frei, "tenho hospedado todos os passageiros [...] tendo feito com esses índios huma casa, e hum pasto grande [...], feito plantar mandioca bastante, e milho, a fim de prevenir as futuras precisões

61 LISBOA, Balthazar da Silva. Op., cit., p. 212-217. 
dos viajantes"62. Ou seja, a posição geográfica do aldeamento e a produção agrícola dos índios aldeados em Ferradas eram sistematicamente utilizadas para atender à demanda do fluxo de pessoas que por ali transitavam.

A estrada que passava pelo aldeamento de Ferradas era de fundamental importância para o desenvolvimento econômico da região; e supomos que Balthazar tinha clareza da situação quando comprou terras e, subsequentemente, instalou a aldeia de Gueréns e Camacãs naquela localidade. Os índios aldeados deram suporte à abertura e conservação da estrada e isso tornou possível o trânsito de pessoas e mercadorias. Ou seja, a localidade funcionava como um corredor de trânsito regional e tornou-se, posteriormente, uma área visada e valorizada.

\subsection{Atuação dos capuchinhos no Aldeamento São Pedro de Alcântara}

Fr. Ludovico de Liorne que com Zelo verdadeiramente Apostolico, sem attender a fadigas, privações, incomodos, e perigos de vida deliberou-se hir pessoalmente por entre as tenebrosas e assustadoras Mattas da Comarca dos Ilheos em procura de Indios bárbaros e Selvagens, só com o fim sublime da Gloria de Deos e Salvação das almas, e utilidade do Estado, e Nação ${ }^{63}$.

As palavras de Frei Ambrósio de Rocca, prefeito do Convento (Hospício) da Piedade da cidade de Salvador,

62 LISBOA, Balthazar da Silva. Op., cit., p. 217-219.

63 AN; Códice 807; volume 2. Relato de Frei Ambrósio de Rocca - Prefeito do Hospício da Piedade - sobre o estabelecimento dos missionários franceses e italianos na Província da Bahia; 24 de janeiro de 1824, fl. 115. 
Província da Bahia, são reveladoras dos direcionamentos adotados para as populações indígenas na primeira metade do século XIX, na província baiana. Essa política indigenista se assentava nos discursos e práticas coloniais reelaboradas pelos interesses imperiais, e correlacionava catequese, civilização, colonização e integração indígena ao projeto nacional.

Em estudo sobre o Aldeamento São Pedro de Alcântara, Paraná (1855-1895), Marta Rosa Amoroso empreendeu esforço no sentido de delinear as estratégias de contato que envolviam os índios, missionários capuchinhos e outros atores, bem como as ressignificações de instituições ocidentais no processo de adaptação social, política e cultural dos Kaiowá, Guarani e Kaingang ${ }^{64}$. No bojo das leituras que compõem essa parte do trabalho, na qual tentamos condensar, brevemente, algumas ponderações acerca da prática capuchinha no século XIX, o estudo de Amoroso é fundamental para entendermos tal lógica.

Amoroso destaca que, para os capuchinhos, os índios eram incapazes intelectualmente e o aprendizado do modo civilizado só se daria pelo uso da imitação, através da mistura com os não índios nos aldeamentos. "[Os] índios aprenderiam convivendo com a gente católica e trabalhadora do Brasil" ${ }^{\prime 6}$. Na perspectiva de Amoroso, a lógica da catequese capuchinha não atendia a fins estritamente religiosos. Os interesses da conversão da alma dos índios ao cristianismo caminhavam lado a lado com o intento da sua conversão aos "modos civilizados". Para Marta Amoroso, o sentido da catequese ia bem além da

64 AMOROSO, Marta Rosa. Catequese e evasão: Etnografia do aldeamento indígena São Pedro de Alcântara, Paraná (1855-1895). Tese de doutorado. USP: 1998, p. 21.

65 AMOROSO, Marta Rosa. Op., cit., p. 252-253. 
instrução religiosa. A pedagogia da catequese tinha por prioridade moldar o índio para o trabalho e inseri-lo na civilização nacional produtiva. Tratando a realidade de fins do Oitocentos, Amoroso define que "os índios figuravam como trabalhadores individualizados de colônias 'mistas' implantadas no sertão do Brasil, embriões de cidades florescentes." 66

Patrícia Sampaio pontuou que no Pará, Maranhão, Espírito Santo e Ceará as missões capuchinhas atuavam desde as décadas de 1830 e 1840, antes mesmo da execução do Regulamento de $1845^{67}$. Isso evidencia que a convocação à ordem religiosa antecede o Regulamento de 1845 e desfaz a ideia equivocada de que a Ordem só começou a fazer parte da estratégia administrativa da governança indigenista imperial a partir do Decreto $n^{\circ} 426$. Na realidade, a partir de 1845 fica legalmente reconhecido e regulamentado o papel administrativo dos capuchinos nos aldeamentos. Desse modo, Cunha salienta que, quando os "missionários são reintroduzidos no Brasil, na década de 1840, ficarão estritamente a serviço do Estado." ${ }^{\prime 8}$ A partir daí, eles se configuraram em peça chave-para a execução do Regulamento das Missões de Catequese.

Em consonância com a fala de Manuela Carneiro da Cunha, Márcia Malheiros, em seu estudo sobre a atuação capuchinha no Rio de Janeiro nas últimas décadas do século XVIII e decorrer do XIX, define que, com a convocação e a atuação capuchinha, o Império "manteve seu ideário de integração e controle dos nativos e de seus territórios, em

66 Idem, p. 255.

67 SAMPAIO, Patrícia Melo. "Política indigenista no Brasil Imperial". In: GRINBERG, Keila; SALLES, Ricardo (Orgs.). O Brasil Imperial, volume I: 1808-1831. Rio de Janeiro: Civilização Brasileira, 2009, p. 180.

68 CUNHA, Manuela Carneiro da. Op. cit., p. 134. 
nome de uma 'causa maior': a expansão da cristandade, a concretização da empresa colonial ou integração, segurança e desenvolvimento do Estado-nação" ${ }^{69}$.

A entrada da administração religiosa capuchinha nos aldeamentos não ocorreu de forma casual, nem, tampouco, foi uma medida isolada de cada província, mas antes resultado de amplo processo de debate e disputa político-parlamentar da década de 1840. A questão envolvia a relação entre Estado e Igreja e dividia as opiniões. Januário da Cunha Barbosa defendia a necessidade do emprego da catequese e missão nas regiões mais afastadas do Império, ou seja, nos espaços ainda não considerados "civilizados". Desse ângulo, a "vinda dos missionários incidira diretamente sobre a estratégia de catequese e civilização dos índios, que o governo tratava como um 'ramo do serviço público" ". ${ }^{70}$

Gonçalves de Magalhães também participou do debate e ressaltava que a ação do Estado deveria caminhar ao lado da ação moralizadora da religião. No entanto, esta proposta deixava claro que a entrada dos missionários capuchinhos no Brasil e sua atuação estariam subjugadas ao governo imperial, demonstrando que o Estado tinha total autonomia diante da ordem religiosa no projeto de catequese dos índios em andamento ${ }^{71}$. Segundo lei maranhense de 1839, os "capuchinhos italianos ficam inteiramente a serviço do governo, que os distribui segundo seus próprios

69 MALHEIROS, Márcia. “Homens da fronteira”. Índios e capuchinhos na ocupação dos sertões leste do Paraíba ou Goytacazes século XVIII e XIX. Tese de doutorado. Universidade Federal Fluminense, Niterói: Rio de Janeiro, 2008, p. 13.

70 KODAMA, Kaori. Os índios no Império do Brasil: a etnologia do IHGB entre as décadas de 1840 e 1860. Rio de Janeiro: Editora FIOCRUZ; São Paulo: EDUSP, 2009, p. 244.

71 KODAMA, Kaori. Op., cit, p. 248. 
projetos"72. Nesses termos, ressalta Cunha, a atuação capuchinha não tinha a mesma autonomia jesuítica "em relação aos projetos governamentais e aos interesses dos moradores, que vigorou em alguns períodos coloniais." ${ }^{73}$

$\mathrm{Na}$ mesma linha, Kaori Kodama demonstra que a atuação missionária capuchinha estava subjugada às diretrizes governamentais do Império do Brasil. Ressalta que a "decisão de importar frades italianos não era, portanto, algo isolado, mas um dos passos que conduziam à busca de uma definição geral da política indigenista, cuja discussão (...) já possuía uma longa trajetória"74.

No Regulamento das Missões de Catequese de 1845, os missionários religiosos tinham, em tese, suas atividades restringidas às funções religiosas. No entanto, como bem ressaltam Cunha $^{75}$ e Kodama ${ }^{76}$, tais atribuições não eram as únicas exercidas pelos frades missionários. Na realidade do aldeamento, era o missionário quem, recorrentemente, assumia todas as funções do aldeamento, inclusive as administrativas. Jerônimo Francisco Coelho, presidente do Grão-Pará em 1849, destacava que "só os missionários poderiam ocupar-se da tarefa de administrar as aldeias e representar os índios, uma vez que havia 'catequese e civilização' dos índios apenas onde estavam presentes os missionários, e de outra forma só haveria opressão e trabalho forçado". ${ }^{77}$

A atuação dos missionários capuchinhos italianos no sul da Bahia se dá desde o início do século XIX.

72 CUNHA, Manuela Carneiro da. Op. cit., p. 140-141.

73 Idem, p. 140.

74 KODAMA, Kaori. Op., cit, p. 249.

75 CUNHA, Manuela Carneiro da. Op. cit., p. 140.

76 KODAMA Kaori. Op., cit. p.250.

77 Ibidem. 
A documentação indica que Frei Ludovico foi o primeiro missionário capuchinho italiano a administrar o aldeamento de Ferradas e chegou à localidade em 1818, pois, em carta redigida pelo prefeito do Hospício da Piedade, em 1824, é mencionado que o frade estava à frente do aldeamento havia 6 anos $^{78}$.

A despeito da escolha de secularização da administração dos aldeamentos a partir do Diretório pombalino, como frisou Cunha, na legislação de 1845, o Império optou pela administração leiga. Entretanto, tal opção se apresentou de forma ambígua, visto que os religiosos, recorrentemente, acresciam ao cargo de missionário, o de diretor da aldeia ${ }^{79}$. Kodama observou que, em muitos casos, por falta de diretores (leigos) competentes, era o missionário que assumia a administração do aldeamento ${ }^{80}$. Portanto, na prática e na maioria das vezes, o missionário assumia o posto de religioso e diretor do estabelecimento. Em São Pedro de Alcântara não foi diferente. Por meio da observação das correspondências trocadas entre autoridades religiosas e governamentais locais e a presidência da Província, verificamos que o aldeamento foi administrado quase exclusivamente por missionários, como se pode conferir na Tabela 1.

78 AN; Códice 807; volume 2. Relato de Frei Ambrósio de Rocca - Prefeito do Hospício da Piedade - sobre o estabelecimento dos missionários franceses e italianos na Província da Bahia; 24 de janeiro de 1824, fl. 115.

79 CUNHA, Manuela Carneiro da. Op., cit., p. 140.

80 KODAMA, Kaori. Op., cit., p. 250. 
TABELA 1 - Administradores do aldeamento São Pedro de Alcântara entre os anos, 1818-1861

\begin{tabular}{|l|l|l|}
\hline PERÍODO & MISSIONÁRIO & DIRETOR \\
\hline $1818-1848$ & $\begin{array}{l}\text { Fr. Ludovico de } \\
\text { Livorno (Liorne) }\end{array}$ & $\begin{array}{l}\text { Frei Ludovico de } \\
\text { Livorno }\end{array}$ \\
\hline $1849-1853$ & $\begin{array}{l}\text { Fr. Vicente Maria de } \\
\text { Ascolis }\end{array}$ & $\begin{array}{l}\text { Fr. Vicente Maria de } \\
\text { Ascolis }\end{array}$ \\
\hline $1854-1855$ & $\begin{array}{l}\text { Fr. Francisco Antônio } \\
\text { de Falerna }\end{array}$ & $\begin{array}{l}\text { Fr. Francisco Antônio } \\
\text { de Falerna }\end{array}$ \\
\hline 1856 & $\begin{array}{l}\text { Fr. Vicente Maria de } \\
\text { Ascolis }\end{array}$ & $\begin{array}{l}\text { Fr. Vicente Maria de } \\
\text { Ascolis }\end{array}$ \\
\hline 1858 & Fr. Rainero de Ovada & Fr. Rainero de Ovada \\
\hline 1859 & $\begin{array}{l}\text { Coronel Egídio Luís } \\
\text { de Sá }\end{array}$ \\
\hline 1860 & Fr. Luís de Grava ${ }^{81}$ & $\begin{array}{l}\text { Coronel Egídio Luís } \\
\text { de Sá }\end{array}$ \\
\hline 1861 & & \\
\hline
\end{tabular}

Fonte: Arquivo Público do Estado da Bahia, Arquivos Coloniais e Provinciais, maços: 2395-I, 2396, 4610, 4612, 4613. ${ }^{81}$

\section{A função dos missionários no Aldeamento São Pedro de Alcântara não diferia das práticas implementadas em}

81 Segundo as observações do historiador Pietro Vittorino Regni, em Os capuchinhos na Bahia, uma contribuição para a história da Igreja no Brasil, Frei Luís de Grava assumiu a administração do aldeamento em substituição a Rainero de Ovada a partir de 1860. Observamos que em correspondência de 1859, Egídio de Sá solicita ao governo provincial um novo missionário, por ocasião da saída do frei Rainero de Ovada. Embora não tenhamos encontrado nenhuma correspondência assinada pelo referido missionário substituto, visto que, depois dessa data, a documentação compilada não faz mais menção ao aldeamento, e sim à colônia agrícola de nacionais, ali estabelecida e dirigida por frei Luís de Grava, a fala do presidente da Província da Bahia, de $1^{\circ}$ de abril de 1860, confirma a nomeação de Luís de Grava, conforme solicitação de Egídio de Sá. 
nível nacional ${ }^{82}$. Grosso modo, podemos elencar: trabalhar os valores religiosos católicos, promovendo batismos e matrimônios; introduzir no aldeamento os modos de vida do branco, bem como incentivar e moldar os índios à rotina do trabalho sistemático para os serviços públicos e particulares.

A fala de Frei Ludovico sobre o andamento do seu trabalho em São Pedro de Alcântara é bem explícita quanto ao papel desempenhado pelos missionários no aldeamento. Em correspondência de 1820, ele registra: “(...) espero que com a constancia e paciência, que Deos me der, hei de vencer outras difficuldades, e reduzilos todos ao bom caminho da Religião, e vassallagem fiel"1"83.

No conjunto das correspondências levantadas sobre o aldeamento, observou-se que os assuntos predominantes eram quase sempre os mesmos: segurança, trabalho, catequese, civilização, colonização. Entretanto, vale ressaltar que, no total das correspondências, bem poucas são das décadas de 1820 e 1830, pois a quase totalidade delas são das décadas de 1840 e 1850. Existe um hiato, portanto, na documentação, mas isso não inviabiliza uma análise que apreenda com certa precisão as demandas administrativas estabelecidas em São Pedro de Alcântara, pois, por meio da documentação disponível, pode-se perceber os fluxos das demandas do aldeamento até 1845 , bem como os assuntos pautados na segunda metade do século (ver a Tabela $n^{\circ}$ 5, Anexo 3).

As comarcas do sul da província da Bahia despertavam maior interesse do governo por dois motivos: era a

82 Sobre o papel dos capuchinhos no processo de catequese nos aldeamentos ver: CUNHA, Manuela Carneiro da (1992); KODAMA, Kaori (2009); MALHEIROS, Márcia (2008).

83 LISBOA, Balthazar da Silva. Annaes do Rio de Janeiro. Editora Leitura: Rio de Janeiro. Tomo VI. 1835, p. 210. 
região mais habitada por populações indígenas, merecendo, assim, atenção governamental no sentido de integrar os índios à civilização e pelo fato de aquela região se apresentar como propensa fronteira de expansão e desenvolvimento agrícola e econômico da província. Desse modo, por volta de 1870, ao contrário do norte da província, onde a orientação era extinguir os aldeamentos por considerar os índios já misturados aos nacionais, o sul chamava a atenção das autoridades, que intensificavam as medidas políticas voltadas para populações indígenas daquela região, na segunda metade do século XIX, haja vista a seguinte orientação:

Indios que devem ser cathequizados, só os há propriamente no sul da província; os mais tem seu princípio de civilização e estão misturados com a população das localidades; por isso manda o director que seria conveniente mandar vender as terras das aldeias, que já não tem índios, e naquellas em que restam alguns, reservar datas de terras, medidas e demarcadas, que lhes sejam distribuídas ${ }^{84}$.

Contudo, nas décadas finais do século XIX, a política direcionada a atender o problema indígena na região sul da Bahia diferia da política empreendida no início do XIX. Naquele momento, em virtude de maiores interesses acerca do trabalho e das terras indígenas para atender aos interesses da lavoura do cacau, o foco do governo se desloca dos aldeamentos, prioritariamente, para o estabelecimento das

84 Fala do presidente da província da Bahia na abertura da Assembleia Legislativa, $1^{\circ}$ de março de 1872, p. 145. In: Falas e Relatórios Provinciais Presidenciais (1830-1930). Disponível em: <http: / / www.crl.edu / brazil/provincial/bahia $>$. 
colônias nacionais agrícolas, mas essa questão será trabalhada em outro capítulo.

No processo de maiores interesses governamentais pelo funcionamento dos aldeamentos, Telma Moreira de Souza observa que a relevância do trabalho capuchinho na região sul da Bahia lhes conferia certa autonomia diante do governo e justificava a acumulação de cargos de diretor e missionário das aldeias ${ }^{85}$. Além disso, a autora ressalta que os capuchinhos "agiam como funcionários do governo, solicitando aumento de salários, pagamento de gratificações, comparando seus salários ou exigindo tratamento igualitário com relação a outro missionário que acusavam de receber tratamento privilegiado do diretor geral" 86 .

Márcia Malheiros ressalta que os estudos acerca das missões de catequese indígena do século XIX não contam com uma profusão de documentação semelhante à encontrada para os estudos coloniais, visto que, ao contrário dos missionários jesuítas que produziram uma ampla massa de documentação com relação a sua experiência catequética, os frades capuchinhos pouco registraram sua atuação religiosa e administrativa nos aldeamentos durante o século XIX. Dessa forma, muito do que se pode inferir sobre a história e as relações entre índios e missionários se consegue a partir de uma leitura, muitas vezes, atenta e a contrapelo da documentação oficial produzida pelo intercâmbio de autoridades locais e autoridades provinciais. Tendo em vista os escritos dos missionários sobre a realidade dos aldeamentos e as relações estabelecidas naqueles espaços, consideramos importantes as cartas trocadas

85 SOUZA, Telma Moreira de. Op., cit., p. 167.

86 Idem, p. 174. 
entre o missionário Ludovico de Livorno e Balthazar da Silva Lisboa, transcritas nos Annaes do Rio de Janeiro ${ }^{87}$.

Estas cartas trocadas entre Ludovico e Lisboa nos permitem afirmar o estreitamento das relações entre Balthazar, responsável pela fundação do aldeamento São Pedro de Alcântara, em Ferradas, e frei Ludovico. Destacaremos, em nossa análise, especialmente, a administração de Ludovico de Livorno pelo fato de ele ter exercido as funções de religioso e diretor do estabelecimento por três décadas, bem como em razão da relevância social adquirida pelo missionário na região, papel e lugar que é recorrentemente frisado e elogiado nas correspondências oficiais do período.

Balthazar exerceu o cargo de ouvidor da comarca de Ilhéus de 1797 a $1818^{88}$. No contexto de troca da primeira carta identificada (1819), ele não era mais ouvidor e tampouco residia na região, haja vista Ludovico mencionar sua ausência e combinar um encontro com ele na ocasião de sua estadia em Rio de Contas. Apesar disso, em todas as cartas o missionário evidencia que as informações eram prestadas por demanda de Balthazar.

$\mathrm{Na}$ primeira carta, Frei Ludovico se refere às acomodações do aldeamento, demografia e situação de deserção por conta de doenças, e explicita que, nessa ocasião, muitos dos aldeados haviam morrido. Relata o missionário que:

87 LISBOA, Balthazar da Silva. Annaes do Rio de Janeiro. Editora Leitura: Rio de Janeiro. Tomo VI. 1835. Nas referidas correspondências, e na escrita regional, ressaltamos que a atuação de Ludovico é descrita como essencial para o êxito da política de aldeamento naquela região. Além disso, é importante observar que a atuação indígena aparece nos relatos do frade à Balthazar e, por isso mesmo, as cartas identificadas são fundamentais para a construção dos nosso objeto de estudo.

88 MARCIS, Teresinha. Op., cit., p.184. 
Os Indios civilisados de Almada são em numero de treze famílias, que formão treze casas arruadas defronte do Templo, que V. S. fez; atraz da Igreja estão as casas dos Camacães em quadrado, que formão huma bonita praça, onde moravão em numero de cento e vinte, porém a moléstia e mortandade, que tiverão neste anno, os obrigou de ir no interior para se curar, e actualmente aqui são poucos, os quaes vão e vem desconfiados do sitio ${ }^{89}$.

No trecho citado acima, fica em evidência que os Camacãs, embora estivessem coabitando um mesmo espaço de territorialização dos Guerens, de certa forma mantinham suas fronteiras étnicas, já que o administrador do aldeamento dispunha de dois núcleos distintos de moradia para ambas as etnias. Nessa perspectiva, lembramos que Frederik Barth ${ }^{90}$ define a fronteira étnica como um processo relacional, isso significa dizer que os sujeitos se identificam etnicamente na interação, organizando-se frente ao seu oposto.

Em São Pedro de Alcântara, os guerens e camacãs construíram espaços próprios e diferenciados, mas próximos entre si, como sugere o relato acima sobre a localização de cada etnia dentro do mesmo espaço de aldeamento. Certamente, as distinções étnicas de cada grupo obrigavam as autoridades a construir espaços díspares para aqueles homens em "situação de aldeamento". Convém ressaltar que não se sabe, por meio da documentação disponível, por quanto tempo existiram as fronteiras étnicas entre eles ou se, no longo prazo, eles terminaram

89 LISBOA, Balthazar da Silva. Op., cit., p. 207-209.

90 BARTH, Frederik. "Grupos étnicos e suas fronteiras". In: POUTIGNAT, Philippe; STREIFF-FENART, Jocelyne. Teorias da etnicidade: seguido de grupos étnicos e suas fronteiras. 2. ed. São Paulo: Ed. UNESP, 2011. 
por se misturar. A bibliografia especializada, a exemplo da de Celestino de Almeida e de Pacheco de Oliveira, sinaliza, contudo, que a territorialização de índios de diferentes etnias em nada prejudica o fato essencial de que o espaço do aldeamento acaba se tornando um território reconfigurado pelos próprios índios aldeados, misturados ou não, tornando-se, para além de um espaço do colonizador, também um espaço de pertença dos índios. Essa discussão será objeto do quarto capítulo.

O fragmento citado acima também nos possibilita perceber o trânsito dos indígenas aldeados, visto que a descrição de que eles "vão e vêm" nos permite supô-los ainda exercendo sua autonomia no processo de aldeamento. Os índios partiam para o interior para se curar das enfermidades. Isso permite inferir que, além de se disporem a viver no espaço territorializado pelo branco, pois saíam e retornavam ao aldeamento, eles ainda tinham acesso aos sertões. Além disso, se partiam "para o interior para se curar", é porque não haviam perdido suas referências e códigos culturais, pois recorriam às suas práticas religiosas e de cura num espaço social distinto do aldeamento. Contudo, mais importante é observar que os Camacãs e os guerens de São Pedro de Alcântara transitavam com certa liberdade em uma fronteira que era fluida, espaço social de interações e de crescente ressignificações.

Dispomos de uma consolidada nova historiografia indígena que tem, entre outros expoentes, Manuela Carneiro da Cunha, Maria Regina Celestino de Almeida, John Manuel Monteiro, Vânia Losada Moreira, na qual os indígenas em "situação de aldeamento" são vistos como sujeitos ativos de sua história. Apesar disso, é inegável o caráter negativo das políticas indigenistas exercidas sobre as populações indígenas ao longo do processo colonizador no Brasil colonial e imperial, que modificaram, até mesmo 
com evidente violência, o curso da história e das vontades desses povos. Dessa forma, em carta datada de 29 de outubro de 1820, frei Ludovico descreve a Lisboa a resistência dos índios associada a um passado que ainda se fazia presente naquelas paragens: a prática do trabalho escravo. Ludovico de Livorno escreve:

\begin{abstract}
[...] Saiba V. S., que eu até agora não estava bem satisfeito delles, por causa da desconfiança em que elles vivião de nós, fundada na tradição de seus antecessores, que os Portuguezes erão seus inimigos, e que os nossos mesmos erão dirigidos a engana-los, e reduzi-los nossos captivos, a qual desconfiança augmentava-se pelo modo com que alguns tratava, e vai ainda tratando com elles, fazendo-os trabalhar quase por força, com ameaça do castigo, e sem nenhum lucro para elles $[\ldots]^{91}$.
\end{abstract}

O conteúdo da carta é revelador: a escravização ilegal dos índios era ainda prática corrente naquela região, bem como a memória e o receio dos índios em relação a isso, taxando como "inimigos" todos os que queriam reduzi-los ao cativeiro. O sul da Bahia despertava o interesse de assentamento de colonos e, nesse processo, o índio era importante tanto como pacificador do território, quanto para servir de mão de obra. Ainda que o Diretório pombalino tenha legalizado o uso do trabalho indígena, estabelecendo a contrapartida de pagamento do serviço prestado, e tendo em vista que, naquele momento, o que vigorava eram decretos, alvarás, resoluções que mantiveram a liberdade dos índios, a documentação testemunha que a prática, no sul da Bahia, era bem diferente. Como bem frisou Manuela Carneiro da

91 LISBOA, Balthazar da Silva. Op., cit., p. 209-211. 
Cunha, "a escravidão indígena perdurou surpreendentemente até pelo menos os meados do século XIX"92.

Outra informação muito importante é o indício de que o aldeamento parecia funcionar como apoio para a formação ou manutenção de outros aldeamentos, pois os indígenas circulavam de forma itinerante pela região. Ao se referir ao decréscimo da população do aldeamento de Ferradas por conta de doenças, frei Ludovico ressalta que os "outros Camacães, que não he pequeno numero, estão aldeados quatro legoas mais para cima, onde não estão sugeitos ás doenças do sitio." ${ }^{\prime 3}$ Ou seja, os aldeados de São Pedro de Alcântara não viviam exclusivamente em Ferradas, e tampouco aquele aldeamento era o único lugar indígena da região.

Em outra carta, datada de 21 de outubro de 1829, que o frade escreve para Balthazar, a quem ele serve como "amigo e criado", segundo palavras do próprio Ludovico, ele segue sua narrativa prestando conta da situação do aldeamento:

[...] Os ditos selvagens, depois de estarem aqui reunidos, cahirão todos doentes, e huma grande parte delles morrerão, de sorte que atemorisados os que ficárão, concentrãose novamente nas suas brenhas, e eu com poucos Indios de Almada fiquei aqui hum anno, sem ter noticia delles. No entanto Deos me deu Constancia, tornei a convida-los, e parte delles vierão, e os outros mais medrosos formarão huma aldêa distante daqui dous dias de viagem, porém todos mansos, e em recíproca correspondência comnosco, e em termo de reuni-los facilmente, quando

92 CUNHA, Manuela Carneiro da. Op. cit., p. 146.

93 LISBOA, Balthazar da Silva. Op., cit., p. 209-211. 
for tempo. Actualmente me acho aqui com noventa e seis indivíduos, e cincoenta na visinha aldêa, esperando a resulta das medidas que o Governo tem tomado acerca do novo abrimento da estrada, e das colônias estrangeiras $[\ldots]^{94}$.

Novamente verificamos o trânsito dos Guerens e Camacãs entre os dois mundos: o mundo que eles tinham por referência social até aquele momento e o mundo do aldeamento, espaço reconfigurado por suas experiências cotidianas. A descrição de frei Ludovico é muito rica para o que pretendemos observar. Permite perceber aquelas pessoas em "situação de aldeamento" como agentes de sua trajetória histórica, vivendo as mazelas da conquista, como as epidemias, mas sem perder, contudo, um relativo controle sobre suas vidas. Ao mesmo tempo em que podemos visualizar os índios de Ferradas agindo com certa autonomia sobre suas vidas, apesar das doenças e de outras dificuldades, percebemos, em contrapartida, a atuação missionária como braço do Estado imperial e dos interesses privados naquela região.

No processo de colonização regional, frei Ludovico estabelece uma teia de comunicações entre diferentes pontos da localidade próxima ao Aldeamento São Pedro de Alcântara. Tal estratégia converge para o próprio propósito de tornar a região pacificada e habitada por colonos. Dois dos pontos que aparecem ao final do fragmento documental citado acima dizem respeito à abertura da estrada IlhéusConquista e à instalação de colônias de estrangeiros na região. Ambas são demandas da política imperial e tinham como fim tornar aquele território habitável e transitável.

94 LISBOA, Balthazar da Silva. Op., cit., p. 214-217. 
Nesse processo, era central controlar os indígenas, pacificá-los, aldeá-los e, de preferência, ainda pô-los a serviço da estrada e dos novos moradores.

Novamente emerge, nessa correspondência entre Ludovico e Balthazar, a divisão dos índios em diferentes aldeamentos. A carta de frei Ludovico sugere que existia um aldeamento oficial, que era Ferradas, cercado por outras aldeias ou aldeamentos. Os índios aldeados em São Pedro de Alcântara, em contextos específicos, dividiam-se e ocupavam outra área próxima ao estabelecimento administrado pelo missionário. Não se pode afirmar que aqueles grupos subdivididos fundavam, na verdade, outro aldeamento; ou se eram aldeias com ramificações em Ferradas, pois o frade não fornece informação suficiente. $O$ mais plausível é interpretar o aldeamento de Ferradas como tendo um núcleo dirigido pelo frei e muitos outros lugares (aldeias) onde os índios viviam de forma mais autônoma, mas sem perder a conexão com o frei e com Ferradas.

Ao final da carta citada, a fala de frei Ludovico novamente nos põe diante dos Camacãs e Guerens de Ferradas como atores que mantinham certa autonomia sobre suas vidas no mundo territorializado: "Respeito á educação moral e civil destes Indios não posso estender minhas vistas acima da capacidade delles, e fóra dos limites destes bosques, pois a experiência me tem feito ver, que fora daqui ficão cheios de vícios, voltão vadios e mestres de impiedade" ${ }^{\prime \prime 5}$. Portanto, nos deparamos novamente com as ideias de Oliveira: o "processo de territorialização não deve ser jamais entendido simplesmente como de mão única, dirigido externamente e homogeneizador" ${ }^{\prime \prime 6}$.

95 LISBOA, Balthazar da Silva. Op., cit., p. 214-217.

96 OLIVEIRA, João Pacheco de. Op., cit., p. 60. 
Ainda segundo João Pacheco de Oliveira, o processo de territorialização deve ser entendido como um processo de via dupla, onde também os índios participam ativamente. Assim, embora os índios se encontrassem num contexto delimitado pelo estado e em situação de homogeneização, na qualidade de índios aldeados, esse espaço sofre ressignificação, na qual os índios são capazes de construir novas identidades étnicas que são evocadas conforme o contexto vivido ${ }^{97}$. Desse modo, os índios, apesar da pressão homogeneizante exercida pela política de aldeamento e catequese, resistem e constroem fronteiras fluidas entre os dois mundos: o mundo do aldeamento dirigido pelo frei, e o mundo de suas aldeias mais ou menos independentes do projeto colonizador. O intercâmbio se dá, além disso, conforme seus interesses, necessidades e as possibilidades de cada momento.

O estudo de Amoroso nos ajuda a entender o movimento entre aldeamento, aldeia mais ou menos independente do centro do aldeamento e sertão. A realidade dos aldeados de São Pedro de Alcântara, no Paraná, estudados por Marta Amoroso, se aproxima da realidade de São Pedro de Alcântara, no sul da Bahia. A autora observa, na documentação utilizada, os termos "círculo urbano" e "aldeias dos índios". Isso significava dizer que os aldeados

97 Idem, p. 56. Na mesma direção de Oliveira, outros autores, a exemplo de Maria Regina Celestino de Almeida $(2001 ; 2013)$ e Vânia Losada Moreira (2010; 2011), trataram da questão da construção da identidade do índio no mundo territorializado, processo no qual as fronteiras étnicas entre aldeados e colonizadores são mantidas na interação entre os dois mundos. Nesse bojo de reflexão teórica sobre a etnicidade, são fundamentais os direcionamentos teóricos de Frederik Barth* como referência fundamental para pensar a ideia de fronteira étnica entre os grupos sociais em situação de contato. *Grupos étnicos e suas fronteiras. In: POUTIGNAT, Philippe; STREIFF-FENART, Jocelyne. Teorias da etnicidade: seguido de grupos étnicos e suas fronteiras. 2. ed. São Paulo: Ed. UNESP, 2011. 
mantinham um trânsito entre o centro administrativo do aldeamento, do qual participavam e se serviam, e as aldeias distantes do centro administrativo, aldeias que abrigavam as distintas etnias: Guaranis, Kaiowás e Kaingangs 98 .

Para Amoroso, a historiografia teria forjado a ideia de que os aldeamentos do Império foram "instituições falidas" e não teriam impactado as populações indígenas, que se mantiveram afastadas. Ao contrário disso, através da ideia da "territorialidade indígena pós-aldeamento", ela percebe o distanciamento mantido pelos índios no processo de contato, e empreende algumas reflexões acerca da evasão dos índios dos aldeamentos, e os dois movimentos são igualmente verdadeiros: a evasão dos índios, bem como sua presença nos aldeamentos paranaenses, criados no século XIX. A autora toma a ideia da análise "multilocal", de Marshall Sahlins, e analisa a atuação dos aldeados transitando dentro e fora do aldeamento, bem como as relações estabelecidas entre esses e os índios não aldeados, como processo de adaptação sociocultural e política das populações que gradativamente apropriavam-se e ressignificavam as instituições ocidentais ${ }^{99}$. Em outras palavras, eles ressignificavam o território imposto pela colonização em um novo espaço de territorialidade, o que Amoroso denomina de "territorialidade indígena pós-aldeamento".

O estudo de Amoroso, nesse sentido, contribui, sobremaneira, para pensarmos a existência do trânsito dos aldeados de Ferradas e a existência das aldeias afastadas do centro do aldeamento. Não notamos, na documentação disponível, a divisão, dessas aldeias independentes do

98 AMOROSO, Marta Rosa. Op., cit., p. 92.

99 Idem, p. 90. 
centro, em etnias demarcadas, ou seja, aldeias separadas uma das outras que abrigassem as distintas populações, subgrupos ou facções, contudo, em certa medida, a realidade de Ferradas se aproxima da situação de fronteira étnica observada no estudo de Amoroso para o Aldeamento São Pedro de Alcântara. Na realidade estudada por ela, as fronteiras entre as diferentes etnias foram rigidamente mantidas no interior do aldeamento, assim como em Ferradas (o centro administrativo do aldeamento), as distintas etnias: os camacãs e os Guerens habitavam em moradias rigidamente separadas, no interior do Aldeamento São Pedro de Alcântara, nos primeiros anos do seu funcionamento.

A ideia de "territorialidade pós-aldeamento" direciona a compreensão de que uma nova territorialidade, envolvendo o aldeamento e o sertão, se construía em Ferradas a partir da realidade de contato e interação. Os aldeados de Ferradas circulavam entre o centro administrativo do aldeamento e as aldeias afastadas do centro, as aldeias mais ou menos independentes, bem como conviviam, nos perímetros do aldeamento, com índios Pataxós não aldeados. Um processo contínuo de ressignificação do sentido do território era construído pelos índios em "situação de aldeamento" e também por aqueles que não eram aldeados, mas que viviam a experiência da colonização na convivência que tinham nos arredores do aldeamento.

Na última carta enviada por Ludovico de Livorno a Silva Lisboa, em fevereiro de 1831, são tratados temas que se tornaram centrais na pauta parlamentar do período, acerca dos direcionamentos para a política indigenista do Império do Brasil: estrada, mão de obra e colonização. Especificamente sobre os direcionamentos provinciais para o sul da Bahia, identificamos a questão do comércio regional. Nesse processo dos acontecimentos, Ludovico tece a seguinte descrição: 
[...] Por tanto participo a V. S. que esta estrada, faz poucos mezes, está novamente aberta, e neste pouco tempo tem vindo dos Sertões para Ilhéus três boiadas, e vários negociantes com diferentes objectos, para experimentar seus negócios, os quaes têem regressado muito satisfeitos pela commoda visinhança [...]. Esta povoação de Indios, que V. S. estabeleceu neste centro, tem contribuído muito ao bom sucesso desta nova estrada [...] Tenho hospedado todos estes passageiros do melhor modo possível, tendo feito com estes Indios huma casa, e hum pasto grande na beira da estrada á margem deste rio, tenho feito plantar mandioca bastante, e milho, a fim de prevenir as futuras precisões dos viajantes, e continuar tudo em boa ordem. Veremos o progresso, e, se Deos nos der vida, darei a V.S. as respectivas noticias mais a miúdo ${ }^{100}$.

Diferentemente do conteúdo das cartas anteriores, essa última tem como tema central a questão do trabalho indígena e sua atuação na estrada, tanto como conservadores dela quanto como produtores de alimentos para o sustento de tropas e de viajantes. O serviço público de abertura e manutenção da estrada representou, durante todo o século XIX, uma das demandas principais do projeto imperial de colonização naquela região, pois se tratava de uma área que deveria funcionar como corredor de comércio e escoamento de produtos. $\mathrm{O}$ aldeamento de Ferradas estava, estrategicamente, instalado naquelas paragens, e a atuação dos aldeados era vital para o bom êxito daquele projeto.

100 LISBOA, Balthazar da Silva. Op., cit., p. 217-219. 
Igualmente importante era a atuação do aldeamento enquanto ponto de apoio para viajantes e fornecedor de produtos de subsistência. Sendo assim, o bom funcionamento da estrada e o trânsito comercial se configuravam em estratégias correlacionadas para tornar habitada por colonos aquela região, atraídos não só pelo emergente comércio entre Ilhéus, Conquista e Minas, mas, sobretudo, pelo crescente interesse pela lavoura do cacau, que já atraía a atenção de colonos estrangeiros e nacionais para aquelas terras do sul da Bahia.

Nesse processo colonizador, ressaltamos a consolidação do Núcleo Cachoeira de Itabuna que, segundo a bibliografia regional, compreende atualmente o município de Itabuna ${ }^{101}$, e teve suas terras ocupadas e exploradas pelos colonos lavradores de cacau. Formaram-se em Itabuna grandes latifúndios da cacauicultura e ela se tornou um dos polos mais importantes da lavoura e exportação de cacau na Bahia. Apenas como ilustração, lembramos que no antigo hino de Itabuna, a cidade ostentava o título de "Rainha da Bahia", a fim de expressar sua representatividade econômica e social no Estado. Realidade possível, primeira e principalmente, pela atuação do aldeamento de Ferradas, que seria extinto no final da década de 1860.

A documentação deixa poucas, mas evidentes pistas de que sobre o antigo aldeamento foi constituída a Colônia Nacional da Cachoeira de Itabuna, que deu continuidade

101Em Crônica da capitania de São Jorge dos Ilhéus, João da Silva Campos, páginas 380-381, observa que: "Mais ou menos em 1860, começou a ser povoado o sítio em que hoje se ergue a cidade de Itabuna, conforme um anuário nela publicado (713), sendo os seus primeiros moradores quase todos sergipanos. Em princípio de 1861 já a câmara de Ilhéus pedia a criação de um distrito policial em Cachoeira de Itabuna, zona onde existia grande pupulação, não somente de naturais do município, como do centro e do norte da província, e de Sergipe que para ali afluíam desde alguns anos atrás". 
ao papel desenvolvido antes pelo extinto aldeamento. Nos registros do Arquivo Histórico Nossa Senhora da Piedade (OFMCap.), Salvador-Bahia, sobre as missões capuchinhas na Bahia, existe o seguinte registro datado de 1926, acerca de uma missão realizada no local de funcionamento da Colônia: "Nesta missão houve pouquíssima concurrencia por ser um logar quase deserto. Este logar foi outrora aldeamento dos [Camacans]"102. O que denota, muito provavelmente, a sobreposição da Colônia ao aldeamento de Ferradas ${ }^{103}$.

As cartas de Ludovico endereçadas a Balthazar, nas primeiras décadas do século XIX, narrando os primeiros anos da atuação do aldeamento São Pedro de Alcântara, demonstram, dentre outros aspectos importantes, aquilo que João Pacheco sinaliza para se pensar o processo de territorialização de modo mais geral, como um processo de mão dupla, no qual entendemos que coexiste a atuação dos índios aldeados e das autoridades que se ocupavam na empreitada de aldeá-los. Nas mesmas cartas, também fica registrada a atuação dos indígenas aldeados no processo de ocupação e exploração daquele território, projeto que, no sul da Bahia, terminou por viabilizar a implantação da lavoura do cacau.

102 OFMCap: Arquivo Histórico Nossa Senhora da Piedade; Caixa Ea-2; Missões - Colônia de Itabuna; ano 1926; p.279.

103 O fragmento citado está fora do marco temporal delimitado para esta pesquisa, no entanto, se faz pertinente citá-lo pela relevância da informação trazida. Não se sabe se o termo empregado na documentação: "Colônia de Itabuna", faz apenas alusão à colônia agrícola ali instalada na década de 1870 ou se o nome permanece após sua extinção, o fato é que o fragmento citado e a sequência do relato do documento deixam evidente que aquela localidade foi, em momento anterior, o aldeamento dos índios de Ferradas. 